\title{
Persistent Organic Pollutants at the Base of the Antarctic Marine Food Web
}

Amy Lee Chiuchiolo

College of William and Mary - Virginia Institute of Marine Science

Follow this and additional works at: https://scholarworks.wm.edu/etd

Part of the Environmental Sciences Commons, Marine Biology Commons, and the Oceanography Commons

\section{Recommended Citation}

Chiuchiolo, Amy Lee, "Persistent Organic Pollutants at the Base of the Antarctic Marine Food Web" (2003). Dissertations, Theses, and Masters Projects. Paper 1539617810.

https://dx.doi.org/doi:10.25773/v5-kten-fe78

This Thesis is brought to you for free and open access by the Theses, Dissertations, \& Master Projects at W\&M ScholarWorks. It has been accepted for inclusion in Dissertations, Theses, and Masters Projects by an authorized administrator of W\&M ScholarWorks. For more information, please contact scholarworks@wm.edu. 
PERSISTENT ORGANIC POLLUTANTS AT THE BASE OF THE ANTARCTIC MARINE FOOD WEB

\author{
A Thesis \\ Presented to \\ The Faculty of the School of Marine Science \\ The College of William and Mary \\ In Partial Fulfillment \\ Of the Requirements for the Degree of \\ Master of Science
}

by

Amy Lee Chiuchiolo

2003 
APPROVAL SHEET

This thesis is submitted in partial fulfillment of the requirements for the degree of

Master of Science

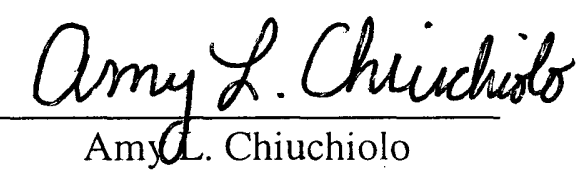

Approved, August 2003

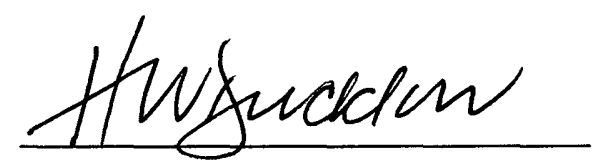

Hugh W. Ducklow, Ph.D.

Committee Chairman / Co-Advisor

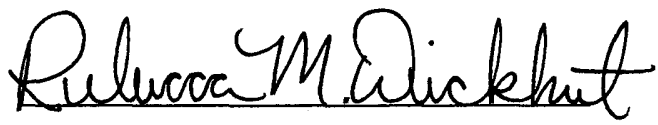

Rebecca M. Dickhut, Ph.D.

Co-Advisor .

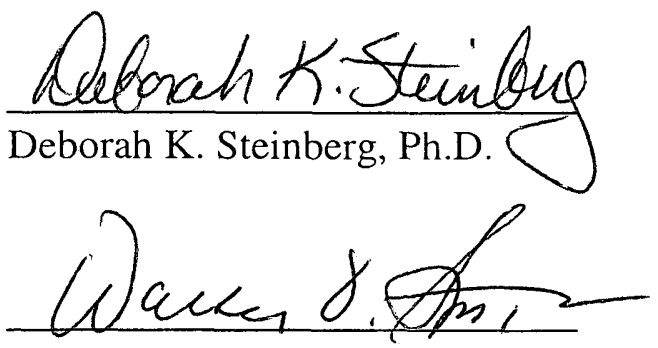

Walker O. Smith, Ph.D. 


\section{TABLE OF CONTENTS}

\section{Page}

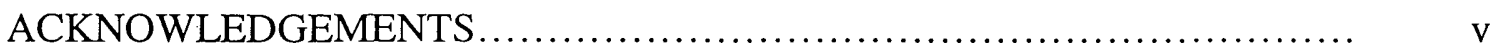

LIST OF TABLES ........................................................... vi

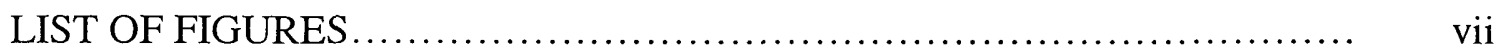

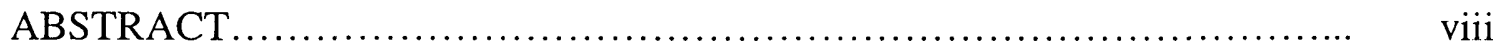

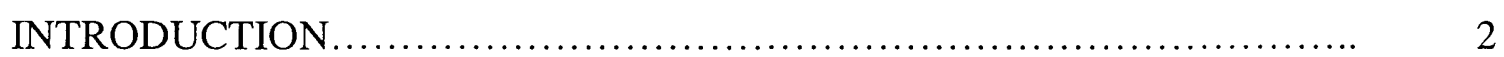

Atmospheric transport of POPs.................................... 6

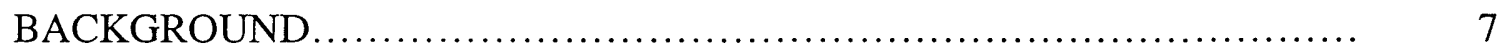

POPs in the Antarctic marine system.................................... 7

Deposition of POPs onto sea ice................................... 7

Incorporation into ice.......................................... 9

Ice melt input.............................................. 10

Summer atmospheric input...................................... 11

Contaminant recycling......................................... 12

Antarctic Ecology ............................................... 13

Water column processes.......................................... 13

Sea ice processes............................................ 15

Contaminants and the food chain.................................... 16

Importance and rationale .......................................... 18

HYPOTHESES ......................................................... 19

MATERIALS AND METHODS ......................................... 19

Winter sample collection........................................ 19

Summer sample collection............................................. 22

Contaminant analyses.............................................. 24

Calculations and statistical comparisons................................. 26

RESULTS AND DISCUSSION ........................................ 27

POPs in sea ice algae............................................... 27

POPs in summer plankton....................................... $\quad 30$ 
Comparisons between winter and summer plankton.................. 32

HCB and BDEs............................................... 32

DDTs, HCHs and heptachlor................................... 35

Spatial and temporal trends...................................... 37

Spatial analysis of POPs in plankton............................. 37

POP temporal trends in Antarctic plankton......................... 38

POPs in krill....................................................... 39

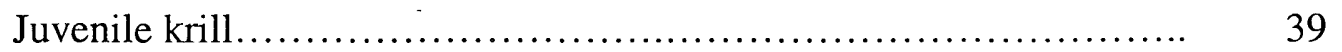

Adult krill................................................... 43

Juvenile versus adult krill...................................... 43

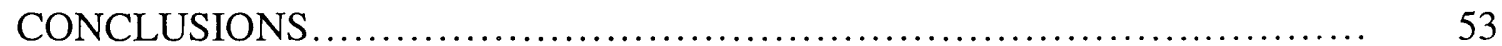

APPENDIX: Pesticide and BDE concentrations in glacier ice, runoff and snow........................................................... 55

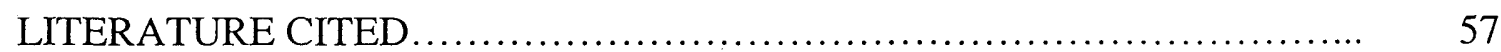

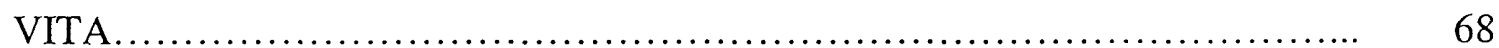




\section{ACKNOWLEDGEMENTS}

I would like to thank my advisors, Drs. Hugh Ducklow and Rebecca Dickhut, for giving me the opportunity to travel to Antarctica. It was a wonderful experience, during which I learned a great deal scientifically, and was also able to see an amazing place. Thank you to Rebecca for patiently teaching me the basics of organic chemistry and for always taking the time to answer my many questions, and to Hugh, who kept me in touch with the biological aspects of my project, and was also great fun in the field! Thank you also to my committee members, Debbie Steinberg and Walker Smith, for keeping me on my toes with all the biology.

A special thanks to Michele Cochran, who spent many hours cleaning the GCMS after my goopy samples had been run. Also, thanks for teaching me the lab techniques of organic chemistry. You're a great teacher! Thank you also to Alessandra Cincinelli for help in the lab, and to Michele, Shelby Walker and Gene Burreson for help with field sampling.

I have made many great friends during my time at VIMS, but I especially want to thank Bob Daniels for keeping me sane during stressful times, Serena for being a great roommate and friend, and Beth and Stephanie also for their friendship.

I want to give a special thank you to my family - Mom, Dad, Lisa, my new brother Mark, and Babcia, for their love, support and encouragement during the past three years.

I would like to acknowledge the people at the Palmer Station LTER and on the RVIB Nathaniel B. Palmer for their help and support of this project. This project was funded by the National Science Foundation. 


\section{LIST OF TABLES}

$\begin{array}{lll}\text { Table Page } & \text { Pag }\end{array}$

1. Pesticide and BDE concentrations in sea ice algae...................... 28

2. Pesticide and BDE concentrations in summer plankton................... 31

3. Pesticide and BDE concentrations in juvenile krill..................... 41

4. Pesticide and BDE concentrations in adult krill........................ 44 


\section{LIST OF FIGURES}

$\begin{array}{ll}\text { Figure } & \text { Page }\end{array}$

1. Map of sea ice particulate matter and krill sampling stations west of the

Antarctic Peninsula...................................................

2. Map of plankton, glacier ice, runoff and snow sampling sites in the vicinity

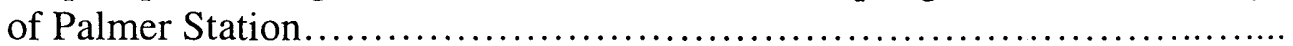

3. HCB and BDE concentrations in sea ice algae and summer plankton.......... 33

4. $\sum-\mathrm{HCH}$ concentrations in plankton from the current and previous studies.... 40

5. Pesticide and BDE concentrations in sea ice algae and juvenile krill......... 42

6. HCB and BDE concentrations in summer plankton and adult krill............ 45

7. Pesticide and BDE concentrations in juvenile and adult krill................ 46 


\begin{abstract}
Data on accumulation of persistent organochlorine pollutants (POPs) in lower trophic level organisms, particularly in the Antarctic, are scarce. In addition, no studies have documented the presence of brominated flame retardants (brominated diphenyl ethers (BDEs)) in Antarctica. This study investigated the presence of various POPs, including $\mathrm{HCB}$ (hexachlorobenzene), $\alpha$ - and $\gamma-\mathrm{HCH}$ (hexachlorocyclohexanes), heptachlor, heptachlor epoxide, o,p' and p,p' DDT and their metabolites o,p' and p,p' DDD, and p,p' DDE, and BDEs (BDE-47, -99, and -100) in sea ice algae, water column plankton, juvenile krill foraging on ice algae, and adult krill, in the Palmer Long Term Ecological Research (LTER) region west of the Antarctic Peninsula during late austral winter and midsummer, 2001-2002. HCB and BDEs were most frequently detected. BDEs were present in ice algae at concentrations between 2 and 3 orders of magnitude higher than $\mathrm{HCB}$. High levels of HCB and BDEs in ice algae indicate the importance of sea ice as a vector for entry of POPs into the Antarctic marine ecosystem. HCHs, heptachlor epoxide, and the DDT compounds were not quantifiable in ice algae samples.

Concentrations of HCB and BDEs were significantly higher in ice algae than in summer plankton. HCHs, heptachlor, heptachlor epoxide, and the DDT compounds were below the level of quantification in more than half of plankton samples. No biomagnification was found in juvenile or adult krill for $\mathrm{HCB}$ or BDEs. $\gamma-\mathrm{HCH}$ and heptachlor were quantified in juvenile krill; $\alpha$ - and $\gamma$-HCH were quantified in adult krill. DDT compounds were not quantifiable in either juveniles or adults. The presence of HCB, heptachlor, and BDEs in ice algae and juvenile krill suggests transfer of contaminants directly from ice algae to foraging juvenile krill. Sea ice therefore contributes contaminants to higher trophic levels directly via feeding by juvenile krill on ice algae.
\end{abstract}


PERSISTENT ORGANIC POLLUTANTS AT THE BASE OF THE ANTARCTIC MARINE FOOD WEB 


\section{INTRODUCTION}

A few decades ago, it was generally assumed that polar regions were unaffected by the increases in industrialization that have occurred over the past century in tropical and temperate regions. Since that time, persistent organic pollutants (POPs) have been found in ecosystems far from areas of production and use, including Antarctica. Furthermore, these contaminants tend to accumulate in polar environments (Wania and Mackay, 1996).

Persistent organic pollutants (POPs) are a class of chemicals, primarily produced and used in low and mid latitudes, which share four characteristics (Voldner and $\mathrm{Li}, 1995$ ). POPs are toxic, long-lived, lipophilic contaminants that have a tendency to evaporate and travel long distances through the atmosphere. A large number of POPs are highly chlorinated, synthetically produced pesticides and insecticides, belonging to a class of chemicals known as organochlorines. These compounds are carcinogenic and endocrine disrupting chemicals that can have harmful effects on both humans and animals, including impaired reproductive success and immune response, and neurological and behavioral abnormalities (Bard, 1999). Such effects occur even at very low concentrations (Schafer, 2002).

Persistent organochlorines (POCs) remain in the environment for extended periods of time before breaking down. Their stability stems from strong chlorine-carbon bonds, which make them resistant to natural degradation processes by light, chemical reactions, 
or biological processes. These compounds are hydrophobic, and generally have low solubilities and high octanol-water partition coefficients (log $\mathrm{K}_{\mathrm{ow}}>4$ ) (Swackhamer and Skoglund, 1991). POCs are also lipophilic, or fat soluble, which results in efficient assimilation by organisms (Larsson et al., 2000). Because of their persistence, POCs are able to remain in body tissue for years or decades before breaking down. The combination of these two factors allows POCs to accumulate in the body fat of living organisms and become concentrated (biomagnified) as they move up the food web via ingestion by higher consumers. Twelve compounds, considered the most toxic of the POPs and referred to as the "Dirty Dozen," are targeted for global elimination by an international treaty signed on May 21, 2001 at the Stockholm Convention (Schafer, 2002). Included in this list of chemicals are several POCs of focus in my study, including DDT (dichlorodiphenyltrichloroethane), hexachlorobenzene (HCB), and heptachlor.

Like the chlorinated POPs described above, brominated diphenyl ethers (BDEs) are another class of persistent, lipophilic, bioaccumulative organic chemicals that travel through the atmosphere, and have an environmental dispersion similar to that of PCBs (polychlorinated biphenyls) and DDT (de Wit, 2002). BDEs are brominated organic compounds, similar in structure to PCBs, that have been produced for use as flame retardants in plastics, textiles, electronic circuitry and other materials since the early 1970's (de Boer and Cofino, 2002; de Wit, 2002). These compounds, like those in the "Dirty Dozen," are speculated to exhibit a number of harmful effects in humans and animals at low-level exposures. Although the toxological impacts are still being assessed, effects of BDEs on thyroid function in animals appear to be similar to adverse 
effects reported for PCBs (Alaee and Wenning, 2002). Evidence also suggests BDEmediated production of pseudoestrogens in humans, neurotoxic effects in mammals, liver toxicity and a reduction in spawning success in fish, and endocrine disruption in aquatic life (de Wit, 2002; Ikonomou et al., 2002). Three general BDE-based flame retardant technical products are produced. Though not the most abundant of these, pentaBDE (PeBDE), containing tetra- through hexa- BDEs, has the highest potential toxicological effects, based on the lower degree of bromination of its congeners. PeBDEs are easily bioaccumulated, and are frequently found in biological and environmental samples. PeBDE products contain a number of lower brominated BDE congeners, including BDE47 (2,2',4,4'-TeBDE), BDE-99 (2,2',4,4',5-PeBDE), and BDE-100 (2,2',4,4',6-PeBDE), which are the BDEs of focus in my study. Unlike the POCs in the "Dirty Dozen," BDEs have not been targeted for elimination by international treaty. BDEs are in current use, and are being commercially produced in large quantities.

As mentioned above, both POCs and the BDEs have a tendency for atmospheric transport. This characteristic has led to their presence in ecosystems far from areas of release. The majority of research on atmospherically transported POCs has been done in the Arctic. There, the accumulation of contaminants has been detected not only in high trophic level seals and polar bears (Oehme et al., 1996; Norstrom et al., 1998; Bard, 1999), but also in breast milk of northern human populations, which have traditionally lived and hunted marine mammals within the Arctic (Bard, 1999). Antarctic sampling programs have also detected the presence of contaminants derived from sources outside Antarctica. The first cases of organochlorine contamination in Antarctica were reported 
in the 1960's with the discovery of DDT and other organochlorine pesticides in Antarctic regions (Sladen et al., 1966; Tatton and Ruzicka, 1967). Since that time, a number of studies on Antarctic organochlorine contamination have been conducted, particularly on high trophic level predators. POCs have been detected in Antarctic fish (Larsson et al., 1992), seabirds (Van den Brink, 1997), penguins (Inomata et al., 1996), Weddell seals (Luckas et al., 1990), in the eggs of both penguins and skuas (Weichbrodt et al., 1999), and in Minke whales (Aono et al., 1997). POCs have also been detected in air, water, snow, ice, aquatic sediments, soils, mosses, and lichens, (Peterle, 1969; Tanabe et al., 1983; Calamari et al., 1991).

Although studies on BDEs in the environment, particularly in polar regions, are far fewer and relatively recent compared to those on POCs, BDEs have been detected in a number of samples in ecosystems far from areas of release. BDEs were first discovered in the Arctic and hypothesized to be global contaminants in 1987, when they were found in tissue samples of fish-eating birds and the ringed seal (Phoca hispida) from the Arctic Ocean (Jansson et al., 1987). Since then, BDEs have been reported in the ringed seal by a number of studies (Ikonomou et al., 2002; Ikonomou et al., 2000; Alaee et al., 1999), in Beluga whales (Alaee et al., 1999), and in Arctic air samples (Alaee et al., 1999). However, no studies have been published to date on the presence of BDEs in Antarctica. Although global elimination of the "Dirty Dozen," as well as the HCHs, is well under way, the BDEs have only begun to be targeted for banning, and only in countries within the European Union (de Wit, 2002). The result is that while levels of POCs have 
decreased in concentration in marine mammals, aquatic wildlife, and human breast milk over the past few decades, levels of BDEs have sharply increased (Li et al., 1998; Alaee and Wenning, 2002; de Wit, 2002). Despite the restricted use of many of the POCs, continuing research on these contaminants is especially important in Antarctica because use of certain compounds, such as DDT, still continues in developing countries, particularly in the tropical regions of the southern hemisphere. Also, even with decreases in the production and use of POCs, these contaminants still enter the Antarctic environment due to evaporation of residues from soils in low latitude regions (Bard, 1999).

\section{Atmospheric Transport of POPS}

POPs reach high latitude regions primarily via long-range atmospheric transport (Wania and MacKay, 1996). Though this transport process has long been accepted for POCs, it was only more recently suggested for BDEs (Watanabe et al., 1992 in Alaee and Wenning, 2002). Because of their high volatility in warm climates, POPs evaporate from the surface of tropical and subtropical regions where they are produced and used. However, cooler temperatures favor condensation and deposition from the atmosphere onto soil and water. POPs therefore migrate to higher latitudes in a series of jumps, known as the "grasshopper effect," by migrating, accumulating, and migrating again in phase with seasonal temperature changes, both as vapor-phase chemicals, and in condensed form adsorbed to atmospheric particles (Wania and MacKay, 1996). 
During this global-scale migration of POPs, fractionation occurs in which individual compounds separate in the atmosphere and are deposited at different latitudes. Highly volatile compounds migrate through the atmosphere faster and remain airborne longer than those with lower volatility. This process results in an accumulation of relatively high volatility persistent pollutants at high latitudes (Wania and MacKay, 1996). While the concentrations of atmospheric POPs decline with distance from low latitude source regions to polar regions (Tanabe et al., 1983), concentrations of relatively mobile POPs condensed in seawater increase over the same distance. Thus, an inverted concentration gradient is established, with low concentrations in tropical regions, and high concentrations in polar regions. Global atmospheric transport of POPs is a chronic source of pollutants, which has led to an accumulation of contaminants in polar regions (Kennicutt and McDonald, 1996).

My study documents the presence of POPs in lower trophic levels of the Antarctic marine food web, and investigates the mode of introduction of these contaminants into the food web.

\section{BACKGROUND}

\section{POPs in the Antarctic Marine System}

\section{Deposition of POPs onto sea ice}

The ice sheet that covers $98 \%$ of the Antarctic continent is the main sink for atmospheric pollution reaching Antarctica (Wolff, 1992). During winter the coastal regions 
surrounding Antarctica are covered with seasonal sea ice, which acts as a lid on the surface of the ocean, accumulating contaminants following deposition from the atmosphere (Pfirman et al., 1995). For the most part, deposition of atmospheric contaminants is not directly onto sea ice, but onto the overlying snow cover. This deposition can occur in the form of both wet (rain/snow) and dry deposition, or via diffusive gas exchange with the overlying snow pack.

Snow is an efficient scavenger of both particulate and vapor phase atmospheric POPs, and is likely the primary transport mechanism for POPs to the ice surface in Antarctic regions. More than $80 \%$ of atmospheric deposition of persistent pollutants in the Arctic happens in the form of snow (Burkow and Kallenborn, 2000). The depositional capability of snow has been seen in the Canadian Arctic, where a single long-range atmospheric transport event deposited thousands of tonnes of fine particulates containing semivolatile organic pollutants ( $\Sigma \mathrm{DDT}, \mathrm{\Sigma HCH}$ ) in "brown snow" (Welch et al., 1991). Contaminants scavenged by falling snow are subsequently contained in accumulating snow packs (Wania, 1997).

Dry deposition, the direct transfer of contaminants in gaseous form or adsorbed to particles, is another possible method of transport for contaminants to the snow and ice surface (Pfirman et al., 1995; Chernyak et al., 1996; Wania et al., 1998). Gregor and Gummer (1989) observed the accumulation of atmospherically transported compounds in the snow pack in a number of sites in the Canadian Arctic, which they propose to be the result of both wet and dry deposition. Diffusive gas exchange may also account for the 
transfer of contaminants to the snow cover, particularly during periods of very low temperature (Hoff et al., 1995; Wania, 1997; Wania et al., 1998).

Incorporation of organic contaminants into the snow pack has been well documented, particularly in Arctic regions and other northern high latitude sites (Wania et al., 1998). Several studies also document concentrations of POPs (DDTs, PCBs, HCHs) dissolved in Antarctic snow (Peterle, 1969; Peel, 1975; Risebrough et al., 1976; Tanabe et al., 1983).

\section{Incorporation into ice}

Wania (1997) suggests that non-polar organic chemicals partition into one of four pools in a glacial snow pack, including the air filling the pore spaces, liquid water, organic material, or the air-ice interface. This partitioning depends on physical-chemical characteristics, with the more water soluble contaminants $(\mathrm{HCH}$, dieldrin) in the aqueous phase, and the less soluble ones (DDT) in the particulate phase (Welch et al., 1991; Wania, 1997). Contaminant transport within the snow pack occurs via diffusion in the air and water contained in pore spaces (Wania, 1997). Unlike glacier ice underlying a glacial snow pack, sea ice is a dynamic medium, constantly shifting and cracking. Contaminants contained in the snow pack overlying sea ice likely percolate into the underlying ice during cracking and seawater flooding. These processes transport organic contaminants deposited on the snow throughout winter into the underlying sea ice.

In ice, organic contaminants are generally found in the dissolved phase, unless a high content of biological material is present (Wania et al., 1998), suggesting that ice algal 
cells are important in accumulating POPs within the ice column. The percolation process described above likely causes partitioning of POPs to algal cells in the ice column. Enhanced association of POPs with particulate matter has been observed in a number of studies, particularly for those contaminants with higher $\mathrm{K}_{\text {ow }}$ (DDTs, $\mathrm{PCBs}$ ), compared to those with low $\mathrm{K}_{\mathrm{ow}}(\mathrm{HCHs})$. High levels of DDT and a PCB isomer were noted in sea ice containing appreciable amounts of particles (Gaul, 1989), while ice samples with low particle content yielded low levels of organochlorines (Hargrave et al., 1988). Also, $\mathrm{HCB}, \mathrm{DDT}, \mathrm{DDE}$, and PCBs were detected in particulate matter collected from the bottom $10 \mathrm{~cm}$ of Arctic pack ice, comprised almost entirely of ice algae, including diatoms and dinoflagellates, while no detectable concentrations were observed in the ice itself (Hargrave et al., 1988; 1992). Other studies also reported contaminant levels in sea ice diatoms, the particulate fraction, and ice algae of Antarctic sea ice, and a high rate of contaminant accumulation in sea ice was suggested (Lukowski and Ligowski, 1988;

Desideri et al., 1991; Green et al., 1992).

\section{Ice melt input}

Few studies have assessed the fate of contaminants entering sea ice. Chernyak et al. (1996) found maximum concentrations of atmospherically transported pesticides in Arctic water samples in regions closest to the ice edge, where ice melt occurs. Similarly, a factor of two increase in PCB content was observed in the surface layer in Terra Nova Bay, Antarctica, following pack ice melting (Fuoco et al., 1994). The introduction of contaminants to surface waters can occur both directly and indirectly. $\mathrm{HCHs}$ and other soluble compounds are likely released with draining melt water (Wania, 1997), while 
chemicals with a lower solubility, such as DDT, are released on organic particles. Volatility increases with temperature, and relatively volatile contaminants, such as HCB, may be volatilized back into the atmosphere during snow and ice melt (Barrie et al., 1992; Pfirman et al., 1995; Wania, 1997). Due to the steep air-water concentration gradient and cool temperature of surface waters following ice melt, these contaminants may condense back into the water column, being introduced indirectly into surface waters.

\section{Summer atmospheric input}

In addition to the pulsed input of contaminants from sea ice melt, atmospheric input continues as a source of POPs to the upper water column throughout spring and summer, making these two sources the major inputs of POPs to the upper water column. Wet and dry deposition are likely lower during summer than winter (Larsson et al., 1992), but airwater exchange may also play a role in introducing POPs into the water column, though volatilization of contaminants from water to air may also occur. Because this exchange is a function of the concentration gradient between the vapor and dissolved phases of the contaminant, as well as wind speed, water temperature, and the physical and chemical properties of the contaminant (Hornbuckle et al., 1994), the direction of air-water transfer is uncertain. 


\section{Contaminant recycling}

While a portion of contaminants released with ice melt is likely lost due to sedimentation and volatilization during spring and summer, some remain in the upper water column via recycling.

During degradation and mineralization of organic matter, organic contaminants, particularly those of higher solubility, are released into solution (Baker et al., 1991). Similarly, efficient recycling of lower molecular weight PCB congeners (3-, 4- and 5chlorines) has been found in lakes (Jeremiason et al., 1999). Contaminant release is often seen during settling of solids through the water column (Baker et al., 1991), but studies describing the recycling of organic contaminants in the upper water column of lakes or the ocean are lacking.

Both microbial respiration and grazing by zooplankton, particularly protozoa, are important in remineralization of organic matter. The presence of a microbial food web, and the importance of grazing and in situ remineralization processes (i.e., POM recycling) during and after the spring bloom in Antarctic coastal regions (Karl et al., 1991; Karl et al., 1996; Serrett et al., 2001; Bode et al., 2002) supports the idea that a portion of contaminants in the mixed layer following ice melt are retained in the euphotic zone due to recycling in the upper water column. Recycled contaminants would be released into solution, and re-distributed into the available particulate pool. In this way persistent contaminants may remain absorbed to phytoplankton in the upper water column, despite multiple generations of phytoplankton between spring and summer. 


\section{Antarctic Ecology}

\section{Water Column Processes}

The Antarctic ecosystem is dominated by the marine environment, with scarce terrestrial life on the continent. The primary food web exists in the marine ecosystem, where life is based almost entirely on microscopic organisms (Friedmann and Thistle, 1993). The coastal environment west of the Antarctic Peninsula is dominated by the seasonal formation and retreat of sea ice, which regulates highly productive phytoplankton blooms (Smith et al., 1995; Smith et al., 1996; Smith et al., 1998a). Vertical stratification induced by the melting of sea ice during spring and summer results in the retention of organisms in a high light and nutrient-rich environment, resulting in increased abundance, biomass, and productivity of phytoplankton (Smith and Nelson, 1986; Smith et al., 1998a). In this region, maximal ice coverage generally occurs during austral late winter/early spring (Sept.-Oct.), with minimal ice coverage during the summer months (Feb.-Mar.) (Smith et al., 1995).

West of the Antarctic Peninsula, phytoplankton accumulate from November to February. During this time chl- $a$ concentrations average $5 \mathrm{mg} \mathrm{m}^{-3}$, with maximum values of $38 \mathrm{mg}$ $\mathrm{m}^{-3}$ in regions of large blooms (Smith et al., 1996). During winter, very low chl-a concentrations $\left(<0.05 \mathrm{mg} \mathrm{m}^{-3}\right)$ are found throughout the water column (Smith et al., 1996). Phytoplankton abundance is also generally low in ice-covered waters during spring (Bidigare et al., 1996). In the immediate vicinity of Palmer Station, biomass begins to accumulate during mid-November. Strong blooms usually develop from December through January, with a relatively large spring bloom during 
December/January, and a smaller secondary bloom in February/March (Smith et al., 1998b).

Coastal Antarctic regions are characterized by a dominance of large plankton, particularly chain-forming diatoms ( $>20 \mu \mathrm{m})$, as well as dinoflagellates, flagellates, and Phaeocystis spp., during the spring and summer seasons (Kottmeier and Sullivan, 1987; Bidigare et al., 1996; Prezelin et al., 2000). Chain-forming diatoms generally dominate during bloom periods in the Palmer Long Term Ecological Research (LTER) area, while smaller diatoms and flagellates dominate during non-bloom periods (Smith et al., 1995). In the Bellingshausen Sea, located west of the Antarctic Peninsula, phytoplankton sampled at the ice edge during October were dominated by Phaeocystis spp., but were replaced by a diatom-dominated community at the beginning of November (Bidigare et al., 1996).

Larger zooplankton (>0.2 mm in length) are the main trophic link between primary producers and apex predators in the Southern Ocean (Ross et al., 1996). The Antarctic krill, Euphausia superba, is the most important macrozooplankton consumer in the Antarctic pelagic food web (Garrison et al., 1986). All Antarctic marine vertebrates depend either directly or indirectly on krill. The predominance of krill in the diets of many species, particularly its importance in the diet of seabirds, seals, and penguins, make it a keystone species in the region west of the Antarctic peninsula (Ross and Quentin, 1986; Ross et al., 1996). Phytoplankton blooms support large populations of these predominantly herbivorous grazers (Holm-Hansen and Huntley, 1984), which are often the most abundant macrozooplankton species within the Palmer-LTER study area 
(Quetin et al., 1996). Adult krill tend to form aggregations and are present year round in the upper $120 \mathrm{~m}$, with an increase in number during late summer/early fall (February through April) (Ross et al., 1996).

\section{Sea Ice Processes}

Sea ice is also a site of high biological productivity (Kottmeier and Sullivan, 1987). The bottom surfaces and interstices of sea ice serve as a microhabitat colonized by bacteria, algae, heterotrophic protozoans, and small metazoans, referred to as sea ice microbial communities (SIMCO) (Garrison et al., 1986, Garrison, 1991; Garrison and Mathot, 1996), or ice algae. These communities may be inoculated with plankton organisms in the water column during ice formation in the austral autumn (Ackley and Sullivan, 1994). Most algal groups present in the plankton community, in particular diatoms, are also found in sea ice (Palmisano and Garrison, 1993). Sea ice, in turn, is hypothesized to provide an important seed stock to developing planktonic populations of ice edge blooms during spring ice melt (Garrison et al., 1986; Garrison, 1991; Ackley and Sullivan, 1994).

Sea ice biota are an important and highly concentrated food resource for over wintering juvenile krill (Holm-Hansen and Huntley, 1984; Ross and Quetin, 1986; Kottemeier and Sullivan, 1987; Stretch et al., 1988; Daly, 1998). Juvenile krill are often observed associated with the undersides of sea ice, and have been found to enter channels within ice floes, which may enable them to forage on biota in the interior of the sea ice (Garrison et al., 1986). Euphausia suberba spawns during summer, and it has been shown that larvae and juveniles cannot survive over winter at ambient food concentrations in the 
water column, and may be dependent on sea ice biota to survive (Smith et al., 1995; Daly, 1998). Observations of adult krill associated with the undersides of sea ice, in contrast, are relatively rare, suggesting that adult krill are not strongly linked with the undersides of the sea ice during winter (Quetin et al., 1996). Evidence suggesting biological production in sea ice to be an important seasonal food resource for juvenile krill indicates an important role for ice biota in the Antarctic food web, and suggests that both SIMCO and water column plankton play a role in forming the energy base of the Antarctic marine food web (Garrison, 1991; Smith et al., 1998a).

\section{Contaminants and the food chain}

The introduction of POPs into surface waters with ice melt coincides with the time of the spring phytoplankton bloom, and a time when stratification induced by the melting of sea ice will concentrate POPs in the upper water column. This could lead to efficient transfer of the pollutants to phytoplankton, and subsequently to higher trophic level zooplankton, with sea ice providing a controlling vector for entry of POPs into the Antarctic ecosystem.

Hydrophobic contaminant concentrations in aquatic organisms are magnified by trophic interactions, beginning with phytoplankton (Taylor et al., 1991). Due to the hydrophobic nature of organic pollutants, and the lipid-rich characteristics and relatively large surface area of plankton, POPs exhibit an enhanced association with these cells (Swackhamer and Skoglund, 1991, 1993; Bard, 1999). Uptake of POPs by phytoplankton occurs via concentration dependent surface adsorption, and subsequent diffusive absorption and 
partitioning to intracellular lipids (Joiris and Overloop, 1991; Swackhamer and Skoglund, 1991; del Vento and Dachs, 2002). Contaminants sorbed to phytoplankton cells are available for consumption by grazing zooplankton, which comprise the next trophic level in aquatic ecosystems. Upon grazing, contaminants are partitioned to lipid-rich organelles and tissues (Hargrave et al., 1988 in Bard, 1999), resulting in bioaccumulation of the pollutants. POPs are transferred with high efficiency between trophic levels, leading to biomagnification with each level (Larsson et al., 2000), expressed as an increase in contaminant concentration on a lipid basis. Both POCs and BDEs are subject to high assimilation and biomagnification through the food web, and have been referred to as "bioaccumulative chemicals of concern" (Wania and MacKay, 1996).

Pfirman et al. (1995) suggest a similar scenario for the Arctic, where pollutants released from ice melt may easily enter the food chain. Organisms feeding on the spring bloom in regions where first year ice melts may be subject to elevated levels of contaminants released from the ice. This mode of contaminant release could have such detrimental effects as contaminating Arctic shore fisheries and bird feeding areas. Although no studies have measured the accumulation of contaminants directly from melting sea ice, high concentrations of contaminants in phytoplankton located in areas fed with water from melting glaciers or old melting icebergs in Antarctica (Lukowski and Ligowski, 1987, 1988) suggest a similar mechanism. 


\section{Importance and Rationale}

Work on the accumulation of POPs in polar biota has focused primarily on higher trophic level organisms. Less research has been conducted on lower trophic level organisms, particularly in the Antarctic. Few studies contain information on contamination of Antarctic phytoplankton by POPs (Lukowski and Ligowski, 1987, 1988; Joiris and Overloop, 1991). Information on the accumulation of atmospherically transported POPs by Antarctic sea ice microbial communities is also scarce, and limited to two studies (Lukowski and Ligowski, 1988; Desideri et al., 1991). Information on organochlorine contamination in Antarctic krill is more abundant (Risebrough et al., 1976; Lukowski, 1978; Gupta et al., 1996; Corsolini et al., 2002), but is still limited, and there is no previous documentation on the transfer of pollutants directly from ice algae to foraging juvenile krill. In addition, information on the presence of BDEs in Antarctica is severely lacking, and no investigations on the presence of BDEs in lower trophic levels in general have been published.

An understanding of the physical and biological processes involved in the input, accumulation, and mobilization of POPs into food webs in polar marine environments is important in predicting the impacts of these contaminants on polar ecosystems. More research on POPs has been done in Arctic environments, and an increased understanding of the processes controlling the fate of these pollutants in Antarctic regions is needed. The time scale over which remote ecosystems can recover from exposure to these chemicals is still unknown (Bard, 1999), and further research and understanding of the 
physical and biological processes regulating pollutant fate in polar ecosystems is essential.

\section{HYPOTHESES}

My thesis focuses on the role of both ice algae and phytoplankton in providing the first step in pollutant transport up the food chain.

1). I hypothesize that POPs incorporated into sea ice throughout winter preferentially absorb to and accumulate in ice algal cells. Following accumulation during winter, POPs are released to surface waters with the seasonal melting of snow and sea ice during the austral spring, and are accumulated by plankton cells in the water column.

2). I hypothesize that during winter ice cover, POPs are passed to juvenile krill feeding on ice algae, and are potentially biomagnified between these two trophic levels.

Likewise, POPs are transferred from phytoplankton to adult krill at the next trophic level, with a potential biomagnification between these trophic levels.

\section{MATERIALS AND METHODS}

\section{Winter Sample Collection}

Ice and juvenile krill samples were collected in Austral late winter/early spring during the 2001 Palmer-LTER Ice Cruise (September 7 - October 26) aboard the RVIB Nathaniel B. 
Palmer. Samples were collected at ice stations located west of the Antarctic Peninsula, southwest of Adelaide Island, at ca. $69^{\circ} \mathrm{W}, 68^{\circ} \mathrm{S}$ (Figure 1).

Sea ice was sampled using a 1 meter ( 3 inch diameter) barrel corer. Cores were taken after clearing the overlying snow from a ca. $2 \mathrm{~m}^{2}$ area to expose the sea ice. Due to the variability in sea ice thickness and structure, and under rafting of the ice, not all cores reached the maximum thickness of the ice. Ice cores were cut into pieces, placed into closed (air and water tight) $60 \mathrm{~L}$, solvent rinsed, stainless steel containers, and transported back to the ship. Subsequently, ice samples were melted by placing the containers in a warm water bath, and filtered to collect particulate matter on a pre-ashed (4 hrs @ 400 $\left.{ }^{\circ} \mathrm{C}\right) 142 \mathrm{~mm}$ diameter glass fiber filter (Gelman Type A/E). The filtrate was passed through an Amberlite XAD-2 (Supleco) resin column ( $35 \mathrm{~cm} \times 25 \mathrm{~mm}$ i.d.) to collect dissolved phase pollutants at $\approx 100 \mathrm{~L} / \mathrm{min}$. The XAD-2 resin was previously cleaned following procedures outlined in Dickhut and Gustafson (1995). Melted ice from three $60 \mathrm{~L}$ containers $(\approx 100-130 \mathrm{~L})$ were combined into one sample $(n=4)$. Filters were packed in pre-washed and ashed $\left(4 \mathrm{hrs} @ 400^{\circ} \mathrm{C}\right)$ Qorpak glass jars and frozen at $-80^{\circ} \mathrm{C}$ until analysis.

Juvenile krill were collected with clean aquarium nets from the undersides and between rafted surfaces of the sea ice by divers $(n=2)$. Samples were frozen in pre-cleaned glass jars at $-80^{\circ} \mathrm{C}$ until analysis. 
Figure 1. Locations of sea ice particulate matter and juvenile krill sampling stations (numbered 1-6) during the 2001 Palmer-LTER Ice Cruise, September 7 - October 26, aboard the RVIB Nathaniel B. Palmer, and adult krill sampling stations (circles), during the Palmer-LTER summer cruise, January, 2002, west of the Antarctic Peninsula. 


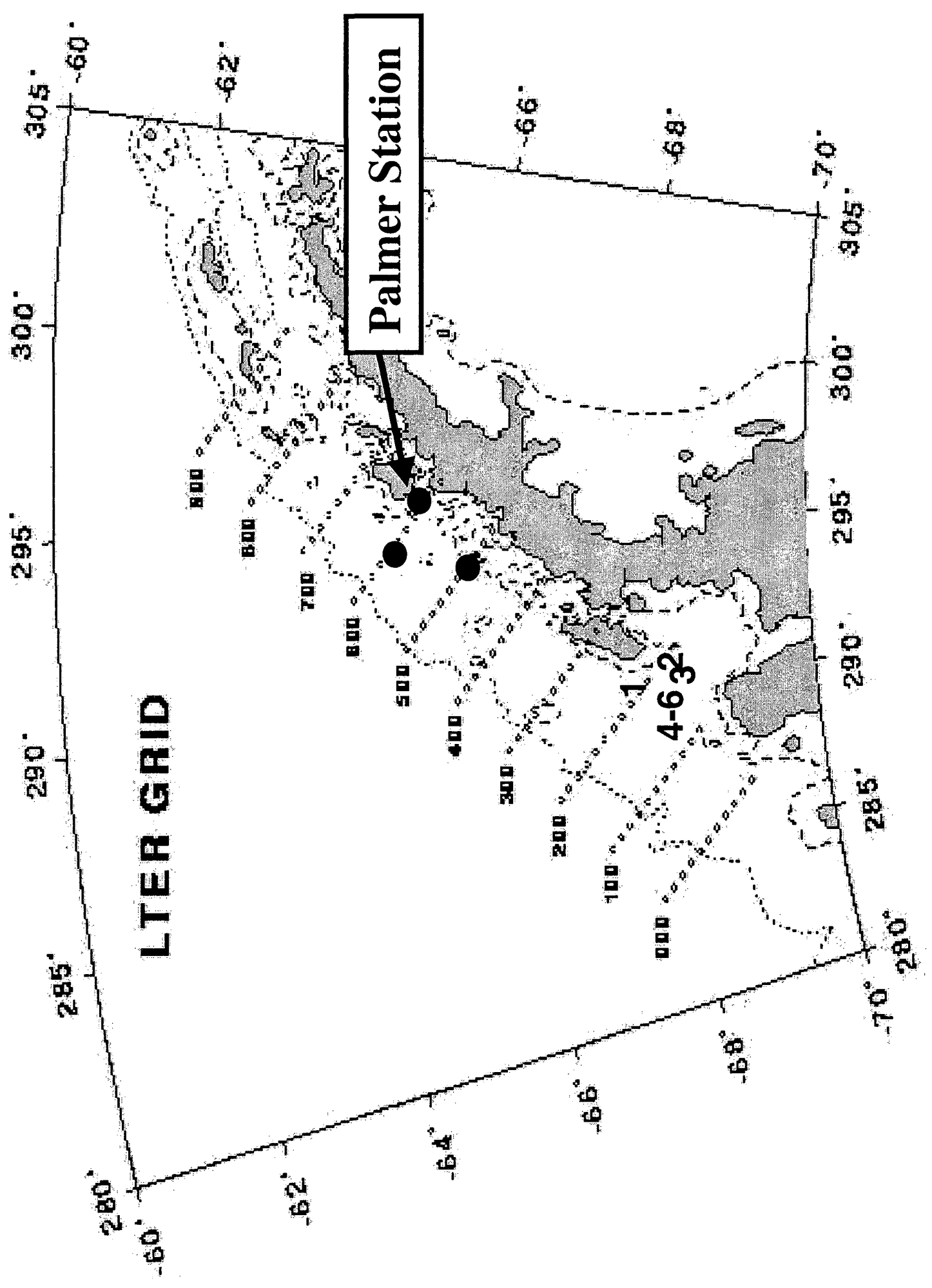




\section{Summer Sample Collection}

Summer sampling took place between January 7 and March 14, 2002, in the vicinity of Palmer Station, Antarctica $\left(64.7^{\circ} \mathrm{S}, 64.0^{\circ} \mathrm{W}\right)$, located in the southwest region of Anvers Island (Figure 2).

Net tows were used to collect representative samples of plankton from the surface water community. Plankton samples $(n=24)$ were collected weekly at 3 stations on the LTER inshore sampling grid (Figure 2), located within 2 miles of Palmer Station. Tows were done via Zodiak using a $153 \mu \mathrm{m}$ net, followed by a $2 \mathrm{~mm}$ sieve to separate out krill and other large, higher trophic level organisms. The net clogged during tows, and it is possible that microzooplankton and small phytoplankton $(<153 \mu \mathrm{m})$ were present in tow samples. A subsample of plankton was identified under 10-20x magnification using a compound microscope following each tow. Plankton samples were found to be composed mainly of diatoms, with a large proportion of Thalassiosira cells. Plankton samples were frozen in pre-cleaned glass jars at $-80^{\circ} \mathrm{C}$ until analysis.

Snow samples (melted $\approx 80-140 \mathrm{~L} ; \mathrm{n}=5$ ) were collected from islands and the glacier in the vicinity of Palmer Station (Figure 2) using solvent rinsed stainless steel shovels, and processed following the methods described above for sea ice samples. Glacier ice from the top of the glacier behind Palmer Station (Figure 2) was sampled (melted $\approx 120-160 \mathrm{~L}$; $\mathrm{n}=3$ ) using a 1 meter ( 3 inch diameter) barrel corer, and processed as described above for sea ice samples. Surface water runoff was collected from a site at the water's edge $\approx 50$ feet from Palmer Station (Figure 2$)$. Runoff samples $(\approx 90 \mathrm{~L} ; \mathrm{n}=2)$ were processed 
Figure 2. Plankton, glacier ice, runoff and snow sampling sites in the vicinity of Palmer Station, Antarctica $\left(64.7^{\circ} \mathrm{S}, 64.0^{\circ} \mathrm{W}\right)$, January 10 - March 14, 2002. 


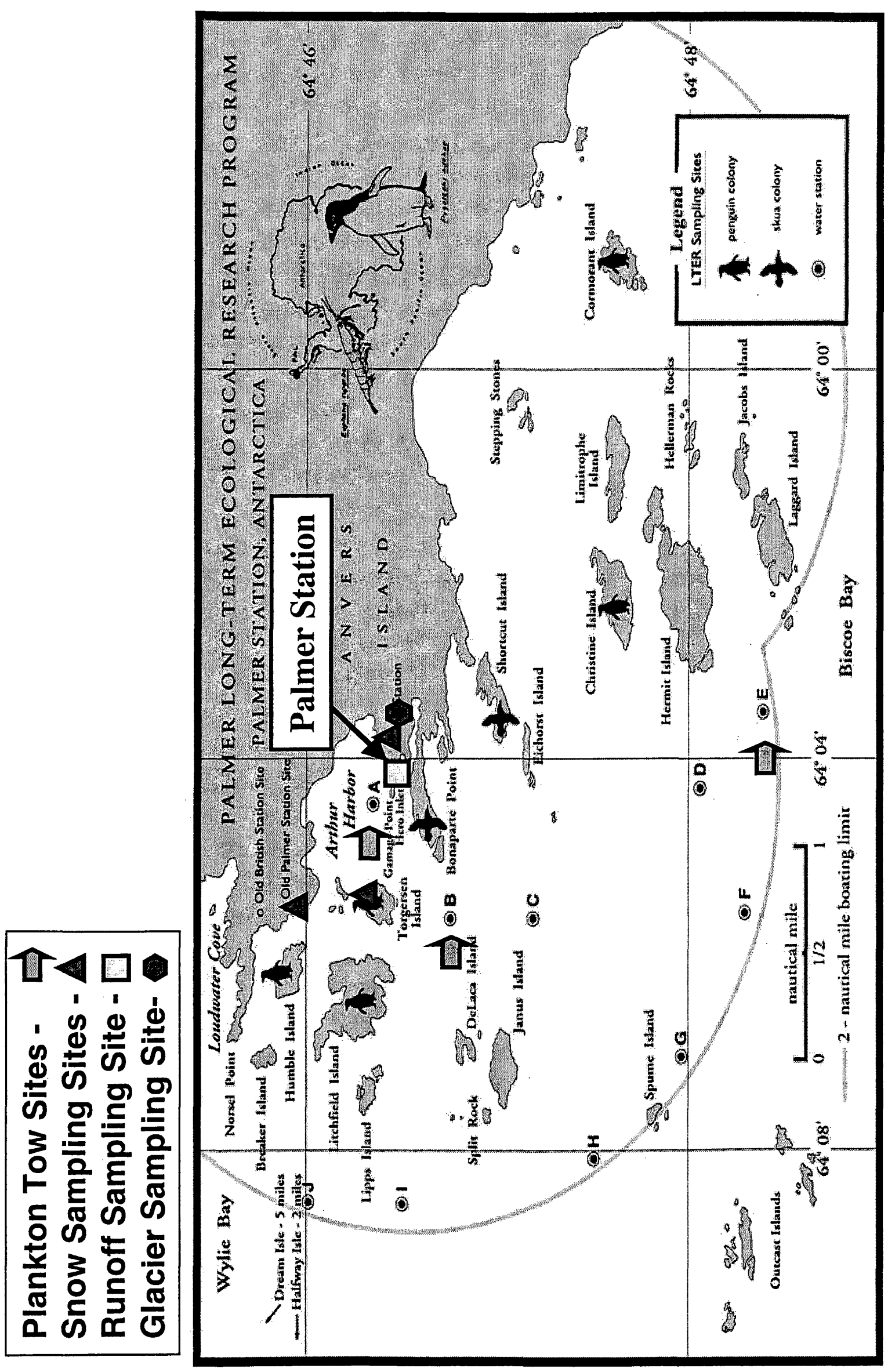


following the above procedures for melted sea ice. Snow, glacier, and runoff filters were packed in pre-washed and ashed $\left(4 \mathrm{hrs} @ 400^{\circ} \mathrm{C}\right)$ Qorpak glass jars and frozen at $-80^{\circ} \mathrm{C}$ until analysis.

Adult krill were collected at stations on the Palmer-LTER regional grid (Figure 1) using a $505 \mu \mathrm{m}, 2 \mathrm{~m}$ ring net during the LTER summer cruise (Jan, 2002) $(\mathrm{n}=3)$. Krill were frozen in pre-cleaned glass jars at $-80^{\circ} \mathrm{C}$ until analysis.

\section{Contaminant Analyses}

Plankton, krill, and sea ice particulate matter (ice algae) were extracted following identical procedures, but preparation of each type for extraction differed. Plankton samples were centrifuged at $1800 \mathrm{rpm}$ for 30 minutes and the supernatant was decanted to remove excess water prior to extraction. Krill samples were homogenized using a Virtis 45 homogenizer prior to extraction. Filters containing sea ice particulate matter were torn into pieces using clean stainless steel forceps prior to extraction.

Each plankton sample (40 - $100 \mathrm{~g}$ wet weight), krill sample ( $\approx 14-15 \mathrm{~g}$ wet weight), and filter sample was thoroughly mixed with pre-ashed $\left(4 \mathrm{hrs} @ 450^{\circ} \mathrm{C}\right)$ hydromatrix (Manufacturer) to remove water, and extracted with 65\%:35\% dichloromethane (DCM):methanol via accelerated solvent extraction (2000 psi; $100^{\circ} \mathrm{C}$; Dionex ASE 200 Accelerated Solvent Extractor) following addition of a surrogate standard mixture containing deuterated $\alpha-\mathrm{HCH}$ and 2,2',3,4,4',5,6,6'-octachlorobiphenyl (OCB). For each sample, the extract was brought to 1:1:0.9 DCM:methanol:water by addition of methanol 
and $20 \% \mathrm{NaCl}$ in hexane-extracted water, and back extracted 3 times into hexane via agitation for 3 minutes. Four of the snow sample filters were Soxhlet extracted for $24 \mathrm{hr}$ each with acetone and DCM instead of ASE extracted after the addition of the surrogate standard. For these samples the acetone fraction was back extracted into hexane as described above and combined with the DCM fraction for solvent reduction.

The hexane/DCM extracts were reduced in volume to $5 \mathrm{ml}$ by turbo- and/or rotoevaporation, followed by blow down with purified $\mathrm{N}_{2}$. The total lipid extract (TLE) was determined gravimetrically for each sample in triplicate by weighing the $5 \mathrm{ml}$ extract, and $0.1 \mathrm{ml}(\approx 20 \%)$ of the extract before and after solvent evaporation at $65^{\circ} \mathrm{C}$. The remaining $\approx 5 \mathrm{ml}$ fraction was vortexed with $1 \mathrm{ml} \mathrm{H}_{2} \mathrm{SO}_{4}$ to remove lipids, and the hexane layer was removed after settling. Approximately $2 \mathrm{ml}$ hexane were added to the remaining extract/acid mixture and the procedure repeated 3 times. A second $\mathrm{H}_{2} \mathrm{SO}_{4}$ clean-up was done on most samples. The acidified hexane fraction was blown down under ultra-high purity $\mathrm{N}_{2}$ to $1 \mathrm{ml}$ and passed through a column containing $10 \mathrm{~g}$ precleaned (Soxhlet extraction with DCM for $24 \mathrm{hrs)}$ deactivated silica (mesh size 100-200), topped with 1 inch pre-ashed (4 hrs @ $450 \mathrm{C}$ ) $\mathrm{NaSO}_{4}$, for further removal of interfering substances. Both $25 \mathrm{ml}$ hexane and 40:10 $\mathrm{ml} \mathrm{DCM}$ :hexane eluents were collected and reduced by roto-evaporation followed by nitrogen blow down to $1 \mathrm{ml}$. An internal standard containing deuterated lindane was added, and the extract further reduced to 100 $\mu \mathrm{l}$ under $\mathrm{N}_{2}$ for analysis. 
Samples were analyzed via gas chromatography/negative chemical ionization mass spectrometry (Hewlett Packard 6890 Series GC system/Hewlett Packard 5973 Mass Selective (MS) Detector) using a J\&W DB-35MS wide bore capillary column (30 m length, $0.25 \mathrm{~mm}$ diameter, $0.25 \mu \mathrm{m}$ film thickness) and selective ion monitoring. Method parameters for pesticide and $\mathrm{BDE}$ analyses are as follows: GC temperature program for pesticide analysis: $70^{\circ} \mathrm{C}$, initial hold time of $1 \mathrm{~min} ; 70-150^{\circ} \mathrm{C} @ 20^{\circ} \mathrm{C} \min ^{-1} ; 150-280^{\circ}$ $\mathrm{C} @ 4^{\circ} \mathrm{C} \min ^{-1}$, hold for $15 \mathrm{~min} ; 280-295^{\circ} \mathrm{C} @ 5^{\circ} \mathrm{C} \min ^{-1}$, hold for $2 \mathrm{~min}$; source temperature $150^{\circ} \mathrm{C}$. Temperature program for $\mathrm{BDE}$ analysis: $50^{\circ} \mathrm{C}$, initial hold time of $1 \mathrm{~min} ; 50-130^{\circ} \mathrm{C} @ 20^{\circ} \mathrm{C} \min ^{-1} ; 130-300^{\circ} \mathrm{C} @ 5^{\circ} \mathrm{C} \mathrm{min}^{-1}$, hold for 6 min; source temperature $150^{\circ} \mathrm{C}$. Carrier gas for both methods: Helium at $1.0 \mathrm{ml} \mathrm{min}^{-1}$ with a velocity of $39 \mathrm{~cm} \mathrm{~s}^{-1}$.

\section{Calculations and Statistical Comparisons}

POPs were quantified relative to surrogate standards and contaminant concentrations are reported per unit of lipid biomass ( $\left.\mathrm{ng} / \mathrm{g}_{\text {lipid }}\right)$. NQ (not quantifiable) in tables 1-4 refers to levels that were below 3 times the field blank (SIMCO filters) or lab blank (plankton and krill). Nd refers to compounds that were not detected on the GCMS. Average values ( \pm standard error) were only reported if compounds were quantified in at least two thirds of the samples. Average HCB concentration in plankton was calculated substituting a lipid normalized blank value for NQ values (Table 2, Figures $4 \& 6$ ). Average $\gamma$-HCH concentration in adult krill was calculated using a value of zero for NQ (Table 4, Figure 7), because this compound was not detected in blanks. Unpaired or paired (where appropriate) $t$-tests were performed on log transformed data to compare average values. 


\section{RESULTS AND DISCUSSION}

\section{POPs in sea ice algae}

Concentrations of HCB and BDE-47, -99 , and -100 averaged $15.9 \pm 6.2,5459 \pm 3840$, $7112 \pm 5913$, and $1350 \pm 1074 \mathrm{ng} / \mathrm{g}_{\text {lipid }}$, respectively, in sea ice particulate matter (Table 1). In contrast, $\mathrm{HCB}$ was not quantifiable in the dissolved phase of the sea ice, and BDEs were only quantifiable in one sample, and may have been due to breakthrough of small particulate material (at or below $3 \mathrm{x}$ blank, unpublished). These results suggest that atmospherically transported POPs that are deposited on sea ice during winter partition onto SIMCO cells.

$\mathrm{BDE}$ compounds were present in ice algae at concentrations between 100-1000 times higher than HCB $(p<0.05$; d.f .=3). One possible reason for this difference lies in the current production and use of these two compounds. BDEs are currently in use and are commercially produced in large quantities. In 1992, the total world production of brominated flame retardants was estimated at 150,000 metric tons/year (de Wit, 2002). In comparison, $\mathrm{HCB}$ is not currently manufactured or used as a commercial end product in the United States, though it is formed as a by-product in the production of several chlorinated chemicals, and is a contaminant in some pesticides. Given the current high production and use of BDEs, atmospheric transport and deposition onto the sea ice is likely higher than for HCB. Moreover, $\mathrm{HCB}$ has a higher vapor pressure and was detected in relatively high concentrations in winter air samples compared to the other 


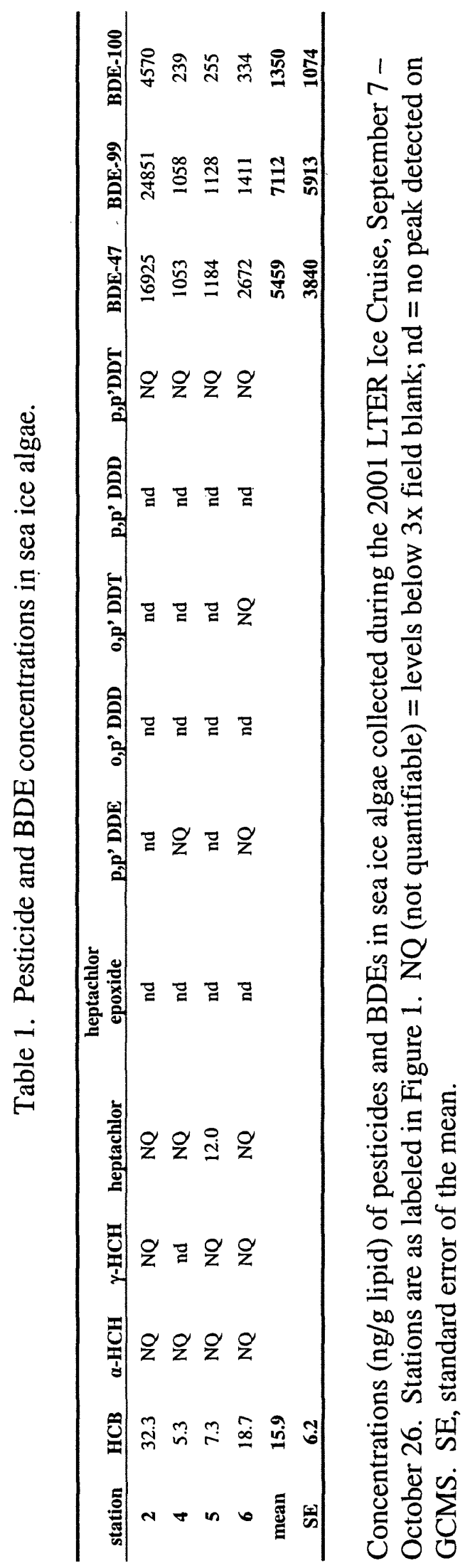


pesticides during my study period (Cincinelli and Dickhut, 2003). The lower vapor pressures of BDEs versus $\mathrm{HCB}$ render the former more easily condensed out of the atmosphere (Wania and Mackay, 1996).

Concentrations of $\alpha$ and $\gamma-\mathrm{HCH}$, heptachlor epoxide, and the DDT compounds were below the level of quantification in sea ice particulate matter, and heptachlor was only quantified $\left(12 \mathrm{ng} / \mathrm{g}_{\text {lipid }}\right)$ in one of four samples (Table 1). Non-quantifiable concentrations of these POCs are likely a reflection of reductions in use in lower latitude regions, leading to low atmospheric concentrations and deposition onto sea ice. Lower atmospheric DDT concentrations (Larsson et al., 1992; Bidleman et al., 1993) compared to those reported a decade earlier indicated that atmospheric DDT levels over the Southern Ocean had dropped in the previous decade. DDTs were not found in air samples taken during my study (Cincinelli et al., unpublished). Likewise, concentrations of p,p' DDE and $\Sigma \mathrm{DDT}$ were higher in sea ice diatoms during the 1986-87 season in the Antarctic Peninsula region (Lukowski and Ligowski, 1988) than DDT concentrations in sea ice algae in my study, which were not quantifiable.

A decrease in use in recent decades ( $\mathrm{Li}$ et al., 1998) is probably the reason for low levels of HCHs, particularly the $\alpha$ isomer, in my ice samples as well. This decrease is supported by the decrease in $\Sigma \mathrm{HCH}$ air concentrations over Antarctica (Cincinelli and Dickhut, 2003). Similarly, although heptachlor is no longer produced or used in the United Nations Economic Commission for Europe (UNECE) region, and was banned in the US in 1988, limited use of this compound is still permitted. Heptachlor is also a constituent 
of chlordane, which was still made in the US for export as of 1998. Heptachlor was detected in higher levels in winter air than $\gamma$ or $\alpha-\mathrm{HCH}$ (Cincinelli and Dickhut, 2003), and the limited use of heptachlor may account for its presence in one ice algal sample. Due to the limited detection of heptachlor in samples, the absence of its oxidation product, heptachlor epoxide, is not surprising.

\section{POPs in summer plankton}

Concentrations of $\mathrm{HCB}$ and $\mathrm{BDE}-47,-99$, and -100 averaged $2.5 \pm 0.4,22.9 \pm 3.5,22.3 \pm$ 3.4 and $4.5 \pm 0.7 \mathrm{ng} / \mathrm{g}_{\text {lipid }}$, respectively, in plankton collected during austral summer (January - early March) at Palmer Station (Table 2). HCHs, heptachlor, heptachlor epoxide, and the DDT compounds were below the level of quantification in more than half of the samples; thus, average concentrations were not calculated. The presence of POPs in plankton suggests recycling of POPs introduced during snow and ice melt and/or atmospheric deposition of these contaminants during summer, and subsequent uptake by plankton. However, BDEs were only $\approx 2-10$ times higher than $\mathrm{HCB}$ in summer plankton, suggesting lower atmospheric deposition and bioaccumulation of these POPs in summer compared to winter. 


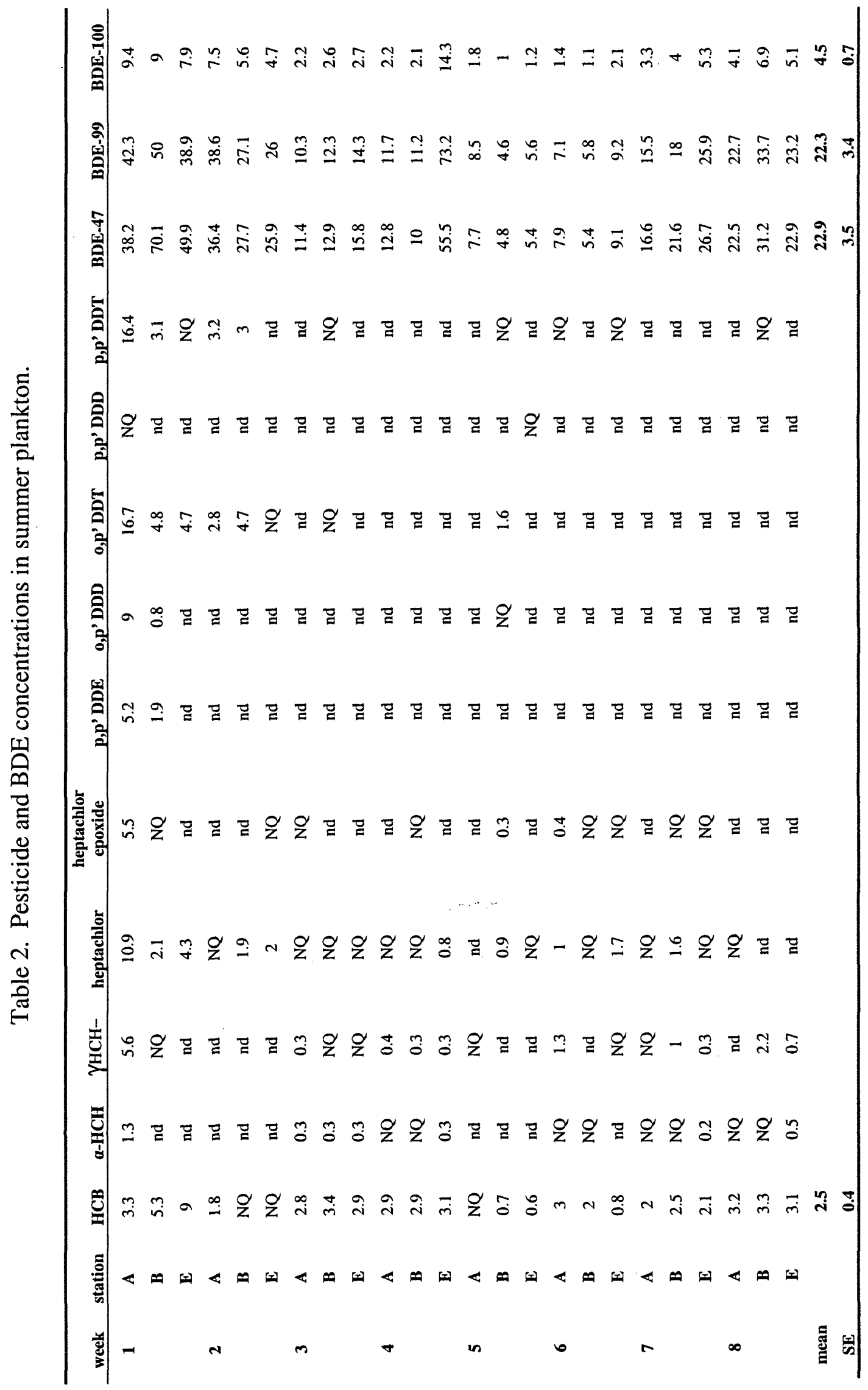




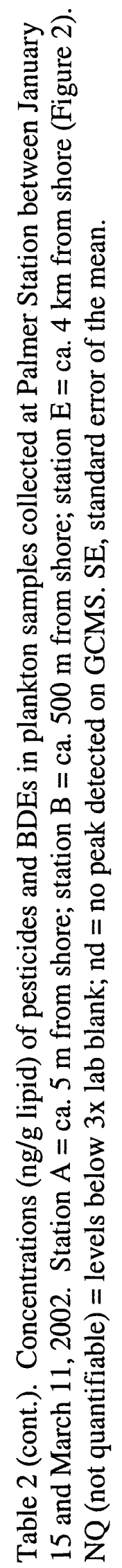




\section{Comparisons between winter and summer plankton}

\section{$H C B$ and $B D E s$}

A significant decrease was seen between the concentrations of HCB and BDEs $\left(\mu \mathrm{g} / \mathrm{g}_{\text {lipid }}\right)$ in summer plankton vs ice algae ( $<<0.05$; d.f. $=26$ ) (Figure 3$)$. This difference can be attributed to a number of processes, including:

Particle flux

One mechanism responsible for the decrease of POPs in algae from winter to summer is removal, or scavenging, of POPs from the euphotic zone between the winter and summer sampling periods, via sedimentation of particles following ice retreat.

Phytoplankton blooms in the marginal ice zone around the Antarctic Peninsula are followed by high rates of POC export (Anadón et al., 2002). The region surrounding the Antarctic Peninsula exhibits extreme seasonality in particle flux (Karl et al., 1991), and in the Bransfield Strait, more than $90 \%$ of the annual sedimentation is concentrated in a short period during December and January (Wefer et al., 1988; Wefer, 1989).

Although removal of contaminants on sinking particles has not been documented in Antarctica, vertical sinking of particle-associated pollutants is considered to be a major sequestration process of POPs in marine environments (Dachs et al., 2000). Both settling particles and fecal pellets are important for selectively concentrating and removing contaminants from surface waters, shown by 10-100 times higher PCB concentrations on 


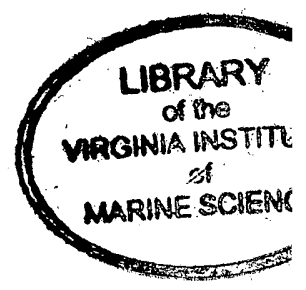

Figure 3. Average lipid normalized concentrations of $\mathrm{HCB}$ and BDEs in wintertime sea ice algae $(n=4)$ and summer plankton $(n=24)$ samples. HCB average in plankton was calculated from 21 samples; 3 samples = NQ (not quantifiable) and a lipid normalized blank value was used for calculation. $*=p<0.05$ for difference between ice algae and plankton (t-test on log transformed data). Error bars represent standard error. 


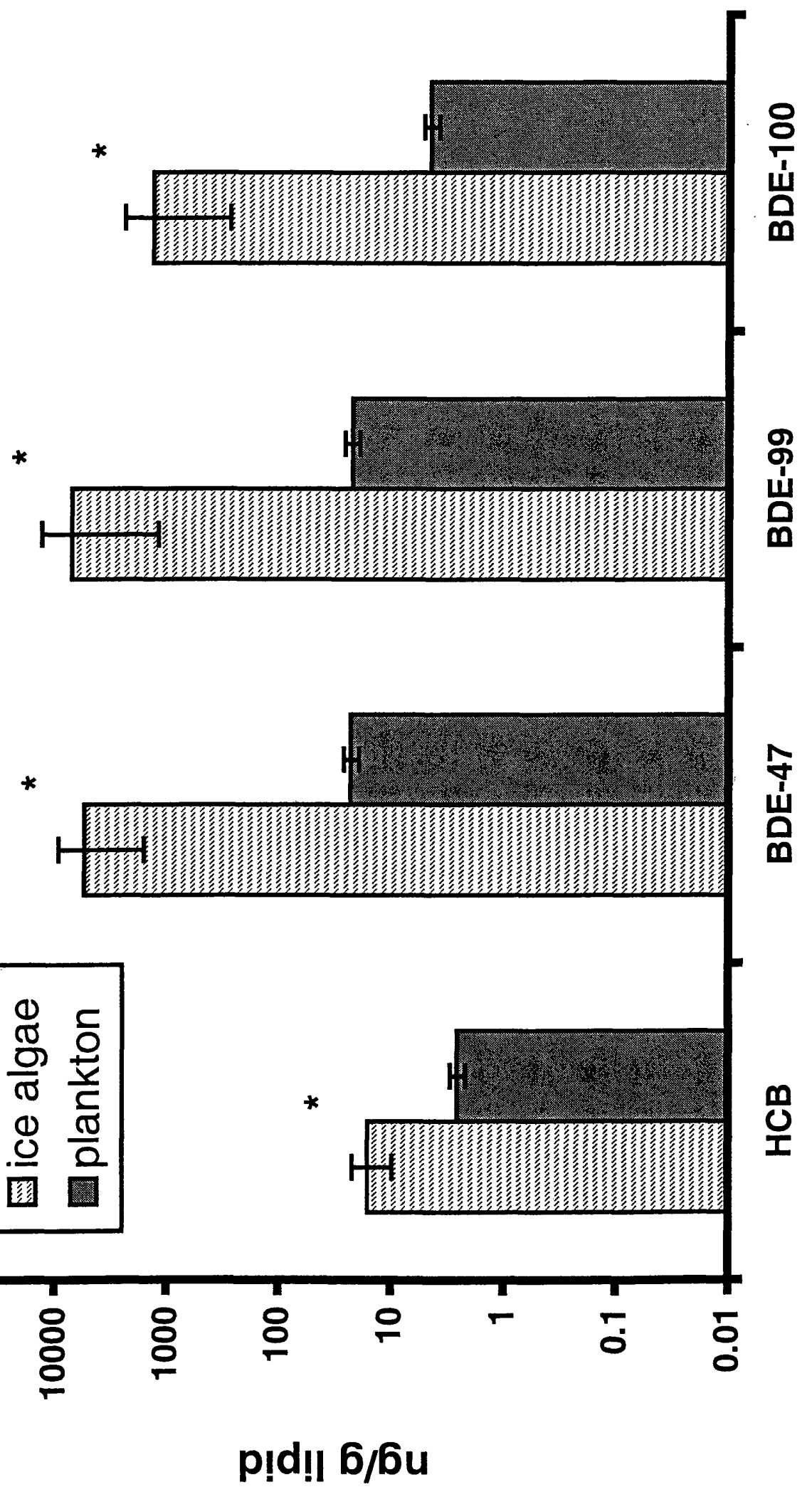


settling than suspended particles (Baker et al., 1991), and up to 21 times higher concentrations in fecal pellets than in the microzooplankton food source (Elder and Fowler, 1977). In the Mediterranean Sea, the seasonality of PCB flux corresponded with cycles of zooplankton biomass and primary productivity in surface waters (Burns et al., 1985). Given the seasonal flux of particulate matter in the Antarctic Peninsula region, a large portion of POPs deposited onto sea ice is likely removed in a relatively short period of time following ice melt.

\section{Biomass dilution}

Higher standing stocks are observed in the summer in the water column (up to $\sim 300 \mathrm{mg}$ $\mathrm{m}^{-2}$ chl- $a$ integrated over the euphotic zone between January and March; Smith et al., 1996) than in the winter ice column (up to $23 \mathrm{mg} \mathrm{m}^{-2} \mathrm{chl}-a$ for sea ice algae; Kottmeier and Sullivan, 1987). The higher biomass during summer likely plays a role in the decrease of $\mathrm{HCB}$ and BDEs between winter and summer samples, through biomass dilution. In this process, an increase in the biomass of plankton cells leads to a decrease in contaminant concentration on a per mass basis (Taylor et al., 1991; Olsson and Jensen, 1975; Larsson et al., 2000). Contaminants recycled in the upper water column until summer, and those added via atmospheric input during spring and summer, were diluted in comparison to concentrations in ice algal communities, resulting in lower levels of $\mathrm{POP} / \mathrm{g}_{\text {lipid }}$ plankton in summer than in winter samples. 
Air flux

Lower atmospheric deposition fluxes or efflux out of surface waters during spring and summer may also contribute to the lower levels observed in phytoplankton during that period. Total aerosol particle fallout is lower during summer (Larsson et al., 1992), and higher air temperatures will result in less condensation of atmospheric pollutants during summer as well (Wania and Mackay, 1996). Volatilization of contaminants from the water to the air may also occur in the absence of sea ice. Although this process is more likely for the more volatile $\mathrm{HCB}$, it may also be possible for the lower brominated $\mathrm{BDE}$ congeners. Hargrave et al. (1997) reported an outgassing of HCB during the ice-free period in the Arctic that could have removed $20 \%$ of the surface layer inventory of this compound, and noted, in particular, a high potential for sea to air flux following ice melt in the Arctic in June. Gregor (1991) suggested volatilization as a mechanism responsible for the summer-time loss of a major portion of the organochlorines deposited in the Arctic snow-pack during winter. Thus, lower atmospheric deposition or volatilization of POPs in summer may in part be responsible for the lower POP concentrations observed in summer plankton than in ice algae.

\section{DDTs, HCHs and heptachlor}

$\alpha$ - and $\gamma-\mathrm{HCH}$, heptachlor and heptachlor epoxide, and the DDTs were present in quantifiable levels in a portion of summer plankton samples (Table 2), while they were below the level of quantification (with the exception of heptachlor, which was quantified in one ice algal sample) in ice algal samples (Table 1). $\alpha$ - and $\gamma-\mathrm{HCH}$ and heptachlor were all found in air and surface waters of the region (Cincinelli and Dickhut, 2003; 
Dickhut et al., unpublished), indicating continued cycling of these POPs between air and water, and promoting accumulation by plankton. However, DDTs were not detected in air or water (Cincinelli et al., unpublished; Dickhut et al., unpublished), suggesting some other source to summer plankton.

\section{Glacier melt input}

One possibility for the presence of DDTs in plankton collected near shore, but not in ice algae samples, is the input of these compounds to surface waters during summer in glacial ice melt. Glaciers accumulate atmospherically deposited contaminants (Gregor et al., 1995; Donald et al., 1999), and melting glacial ice provides a source of contaminant input to surface waters during the spring and summer seasons (Lukowski and Ligowski, 1987, 1988; Blais et al., 2001). In Antarctica, Lukowski and Ligowski (1987) documented higher $\mathrm{HCH}$ and DDT concentrations in plankton close to melting glaciers and icebergs, than in areas removed from glacier melt influence. Lukowski and Ligowski (1988) also found increased concentrations of $\gamma-\mathrm{HCH}, \mathrm{p}, \mathrm{p} \mathrm{DDE}$ and $\Sigma \mathrm{DDT}$ in phytoplankton sampled in areas more heavily covered in glacier ice. In my study, the highest levels of $\alpha$ - and $\gamma-\mathrm{HCH}$, heptachlor and heptachlor epoxide, and the DDTs in summer plankton were measured during the first sampling week (Jan. 15, 2002) at station A (Table 2), $\approx 5 \mathrm{~m}$ from shore in Author Harbor, an area directly influenced by glacier ice melting during summer.

In surface glacier core samples $(0-1 \mathrm{~m})$ collected in conjunction with my study, only heptachlor (dissolved phase) and BDEs (particulate and dissolved) were found at 
quantifiable levels (see Appendix). However, this does not mean that glacier runoff is not a source of DDTs to near shore plankton. Glaciation rates and the age of ice in the top 1 meter where samples were collected are unknown. Therefore, it is possible that DDTs, which were deposited in high amounts during the 1960's (Lukowski and Ligowski, 1987), and the other pesticides, are located deeper in the glacier than the sample depth. Indeed, a previous study, conducted in 1975 in the vicinity of Anvers Island, found the highest amounts of DDT in ice layers from 1.5 to $6.0 \mathrm{~m}$ below the surface (Risebrough et al., 1976). In glacier runoff, DDTs, and to a lesser extent, $\alpha$ - and $\gamma-\mathrm{HCH}$, were found largely in the dissolved phase (see Appendix). Glacial runoff may originate from the surface of the glacier, or from older glacial ice (Blais et al., 2001). Origination of runoff from a source of old glacier ice contaminated with DDTs could have resulted in the presence of DDT compounds in runoff and near shore plankton samples, even though they were not found in upper glacier ice samples.

\section{Spatial and Temporal Trends}

\section{Spatial analysis of POPs in plankton}

Analysis of spatial variations in POP concentrations between the three stations at which summer plankton samples were collected, and the proximity of station A to the source of glacier runoff, can provide insight into the dominant sources of POPs to Antarctic coastal waters. No significant difference was found between any of the stations for concentrations of BDEs or HCB ( $p>0.05$; d.f. $=14$ ), supporting the hypothesis of deposition via atmospheric input, rather than input via glacial melt. Current atmospheric 
input of these compounds is also supported by their presence in ice algae and in air samples (Cincinelli and Dickhut, 2003; Cincinelli et al., unpublished). In addition, current atmospheric input of BDEs is supported by the presence of BDEs in snow samples from Palmer Station, deposited during the sampling year (see Appendix).

DDTs and the other pesticides were not found in a sufficient number of summer plankton samples to allow a statistical analysis of spatial trends. However, as noted above, the increased concentrations of DDTs in near shore plankton samples does implicate glacier ice melt water as the current source of these compounds. It is interesting to note that the ratio of the DDT isomers o,p' and p,p' DDT in plankton samples (Table 2) is close to 1.0. The technical mixture of DDT contains $80 \%$ p,p' DDT and 20\% o,p' DDT (Kannan et al., 1995). Thus, o,p' DDT is generally found in significantly lower proportion to p,p' DDT in the environment. For example, o,p' DDT averaged $17 \%$ of the sum of o,p' and p,p' DDT in fish samples from countries in tropical Asia and Australia (Kannan et al., 1995 in Garrison et al., 2000). No comparisons of o,p' to p,p' DDT exist for Antarctic phytoplankton, although the ratio of o,p' to p,p' DDT in Antarctic air collected during 1994-'95 was 0.71 (Kallenborn et al., 1998). These data may indicate a preferential loss of $p, p^{\prime}$ - relative to o,p' DDT during atmospheric transport to the Antarctic.

\section{POP Temporal trends in Antarctic plankton}

Values for $\gamma-\mathrm{HCH}$, heptachlor epoxide, p,p' DDT and p,p' DDE in plankton were quantifiable in a lower proportion of my samples than in plankton samples taken during 1987 in the Indian Ocean sector of the Antarctic (Joiris and Overloop, 1991). Also, 
average concentrations for those samples in which compounds were quantified are almost two orders of magnitude lower than concentrations reported by Joiris and Overloop (1991). The reduced frequency of occurrence and concentrations of these compounds can be attributed to decreases in use and atmospheric concentrations over the past few decades, which were reflected also in ice algal concentrations discussed above. A similar trend was seen between my data and concentrations of $\alpha$ - and $\gamma-\mathrm{HCH}$ and the DDTs measured by Lukowski and Ligowski $(1987,1988)$ in the Antarctic Peninsula region during the 1983-' 84 and 1986-' 87 seasons. Figure 4 shows the decline in $\Sigma \mathrm{HCH}(\alpha-+\gamma$ $\mathrm{HCH}$ ) over time, yielding an estimated half-life for $\mathrm{HCHs}$ in Antarctic plankton of 2 years.

\section{POPs in Krill}

\section{Juvenile krill}

Average concentrations of $\mathrm{HCB}\left(10.3 \pm 1.4 \mathrm{ng} / \mathrm{g}_{\text {lipid }}\right)$ and BDEs $(568 \pm 209,622 \pm 253$, and $128 \pm 50.5 \mathrm{ng} / \mathrm{g}_{\text {lipid }}$ for BDE-47, 99, and 100, respectively) in juvenile krill (Table 3) were not significantly different from those found in ice algae $(p>0.05$; d.f. $=4)$ (Figure 5), suggesting uptake of these compounds by juvenile krill feeding on ice algae, but no biomagnification between trophic levels. $\gamma-\mathrm{HCH}$ and heptachlor were also quantified in juvenile krill, at average concentrations of $1.3 \pm 0.5$ and $14.2 \pm 12.9 \mathrm{ng} / \mathrm{g}_{\text {lipid }}$, respectively (Table 3). Heptachlor was quantified in one ice algal sample at a similar concentration as in juvenile krill (12 ng/g $/$ lipid $)$, but otherwise, levels of $\gamma-\mathrm{HCH}$ and heptachlor were not quantifiable in ice algae (Table 1). 
Figure 4. $\Sigma-\mathrm{HCH}(\alpha-+\gamma-\mathrm{HCH})$ concentrations in plankton collected in the vicinity of Palmer Station, 2002 and previous studies. Average value for current study was calculated using only those samples in which $\alpha-$ or $\gamma-\mathrm{HCH}$ was quantifiable (Table 2). Therefore, the calculated half-life is a conservative estimate. 


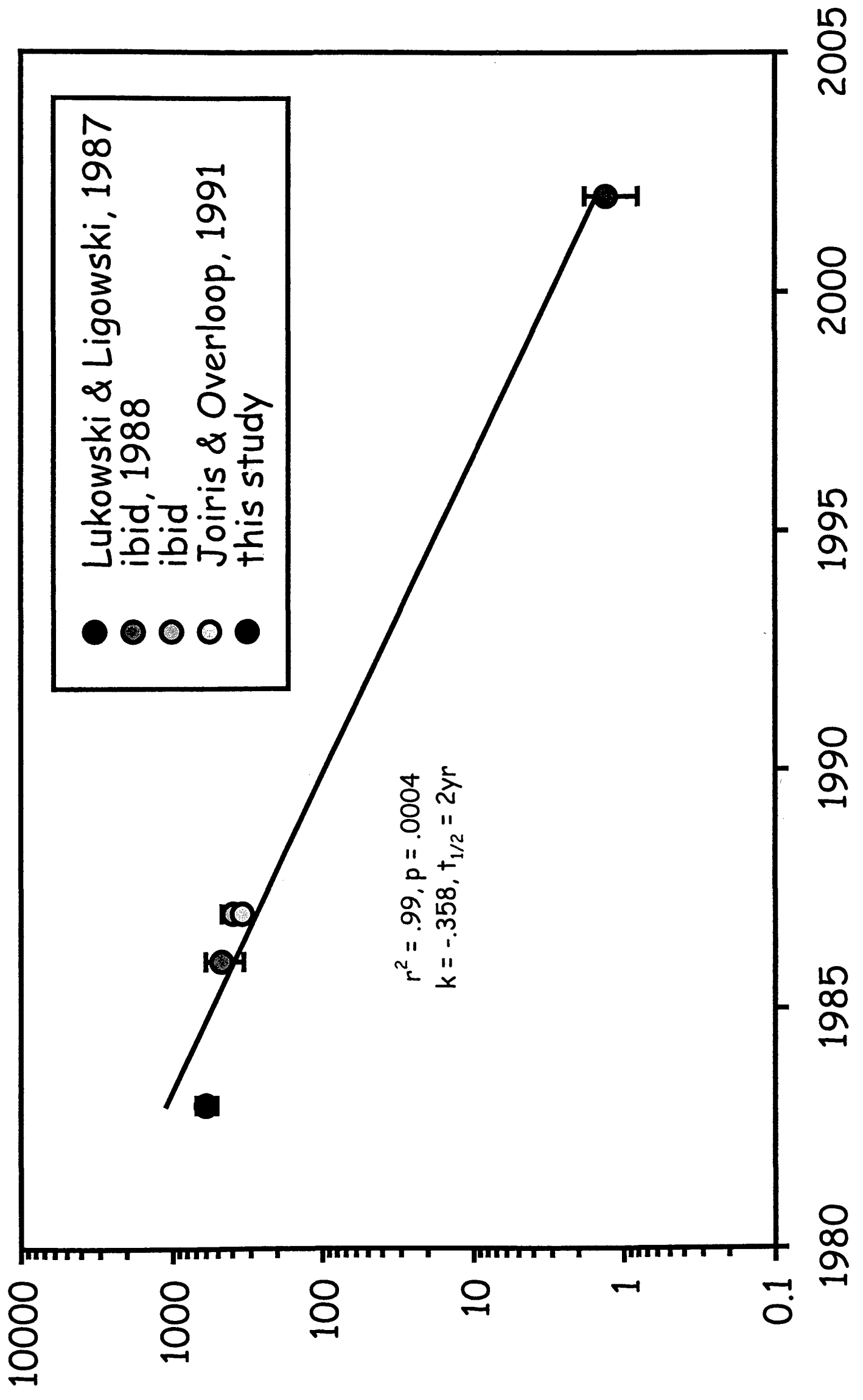

(pid!!6/6u) uotyup|do+kyd u! HOH3 


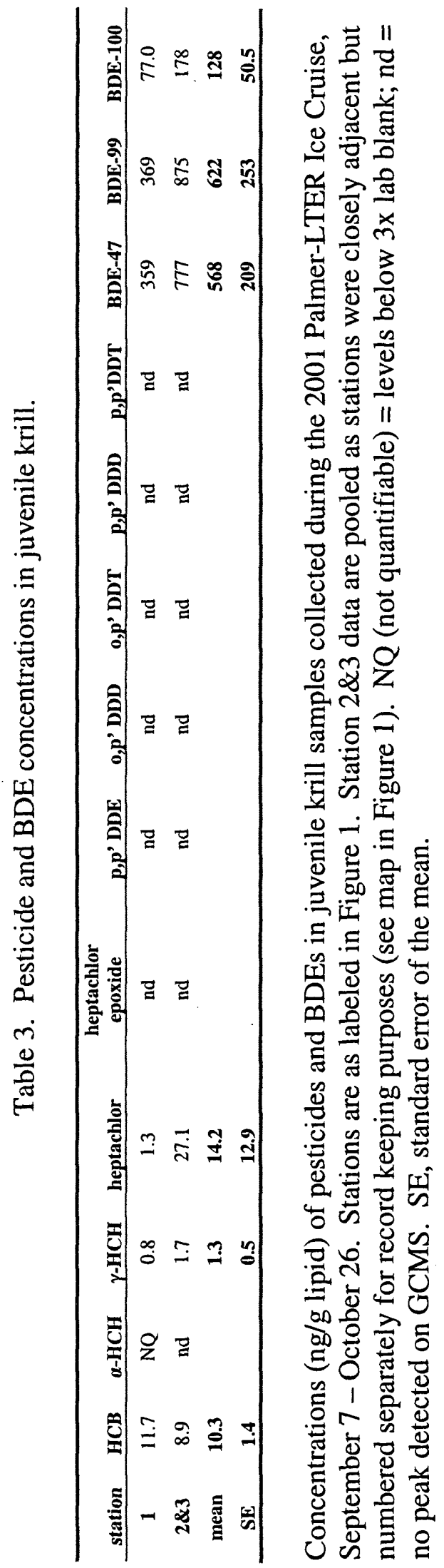


Figure 5. Average lipid normalized concentrations of pesticides and BDEs in wintertime sea ice algae $(n=4)$ and juvenile krill $(n=2)$ samples. Heptachlor was detected in 1 ice algae sample $\left(12 \mathrm{ng} / \mathrm{g}_{\text {lipid }}\right)$, but was not quantifiable in other samples. $\gamma$-HCH was not quantifiable in ice algae samples. All p values $>0.05$ for difference between ice algae and juvenile krill (t-test on log transformed data). Error bars represent standard error. 


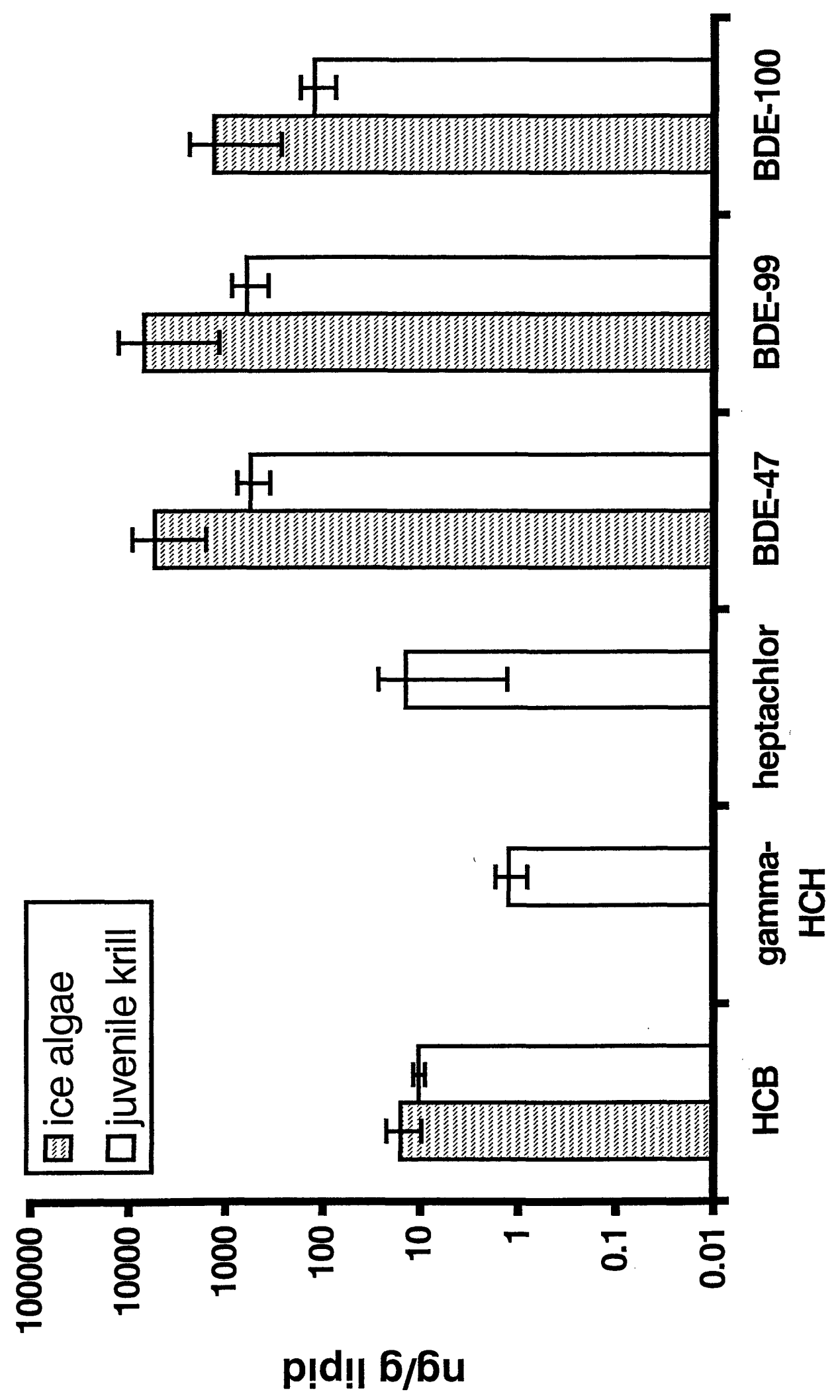




\section{Adult krill}

The average concentration of HCB $\left.(3.8 \pm 0.3) \mathrm{ng} / \mathrm{g}_{\text {lipid }}\right)$ in adult krill (Table 4$)$ was not significantly different from that in summer plankton $(p>0.05$; d.f. $=25)$ (Figure 6). Average concentrations of BDEs in adult krill $\left(2.0 \pm 0.5,2.5 \pm 0.6\right.$, and $0.5 \pm 0.1 \mathrm{ng} / \mathrm{g}_{\text {lipid }}$ for BDE-47, 99, and 100, respectively; Table 4), in comparison, were significantly lower than in plankton $(\mathrm{p}<0.05$; d.f. $=25)$. As with juvenile krill and ice algae, no biomagnification was found between plankton and adult krill. $\alpha$ - and $\gamma$ - $\mathrm{HCH}$ were also both quantified in adult krill (Table 4). Interestingly, $\alpha-\mathrm{HCH}$ was more concentrated than $\gamma-\mathrm{HCH}$ in adult krill, whereas the opposite was true for phytoplankton (Table 2) and juvenile krill (Table 3).

\section{Juvenile versus adult krill}

Concentrations of $\mathrm{HCB}$ and BDEs were significantly lower $(\mathrm{p}<0.05$; d.f. $=3)$ in adult than juvenile krill (Figure 7). Heptachlor was also detected in juvenile krill (Table 3), but it was below quantifiable levels in adult krill (Table 4). Therefore, POP accumulation by juvenile krill during their first year when they are feeding on ice algae appears to exceed that for adult krill. Concentrations of HCB and BDEs were significantly higher on a per lipid basis in ice algae compared to summer water column plankton $(\mathrm{p}<0.05$; d.f. $=26)$ (Figure 3), and the significant difference between juvenile and adult krill may be a reflection of contaminant levels in their food source, or of acquisition of contaminants during the egg stage. 


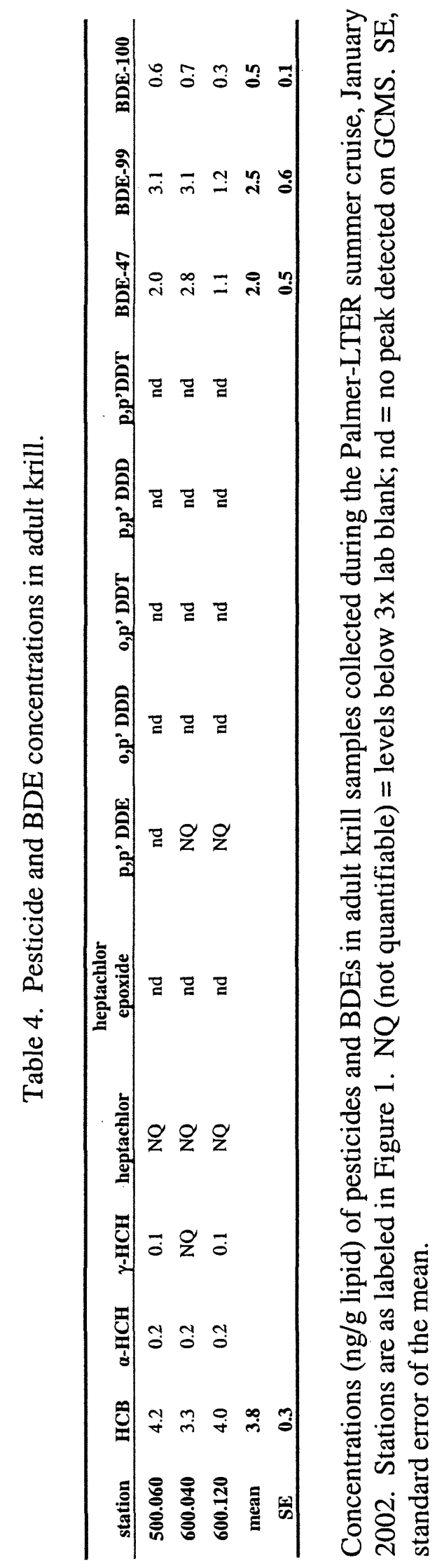


Figure 6. Average lipid normalized concentrations of $\mathrm{HCB}$ and BDEs in summer plankton $(n=24)$ and adult krill $(n=3)$ samples. HCB average in plankton was calculated from 21 samples; 3 samples $=\mathrm{NQ}$ (not quantifiable) and a lipid normalized blank value was used for calculation. ${ }^{*}=\mathrm{p}<0.05$ for difference between plankton and adult krill (t-test on log transformed data). Error bars represent standard error. 


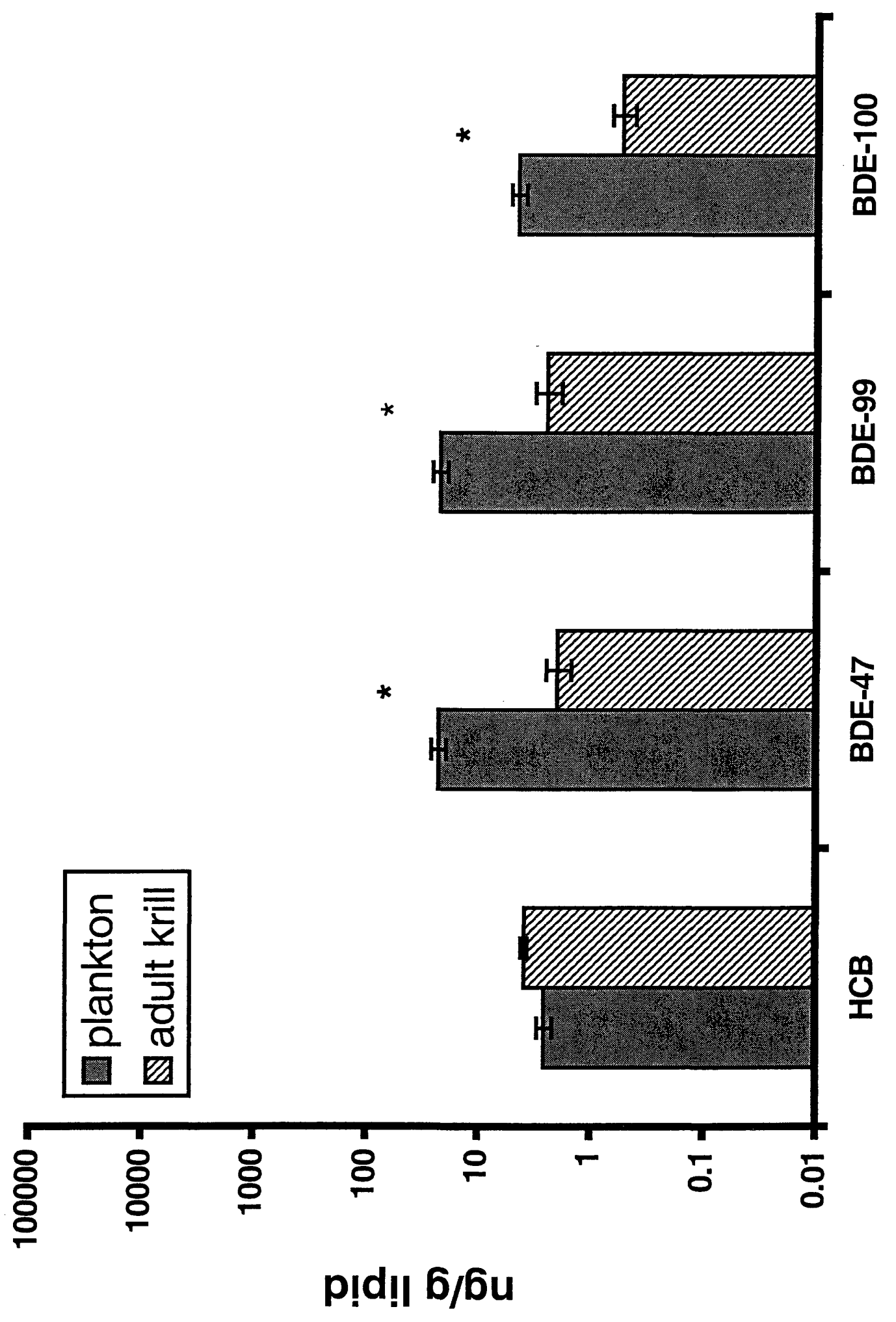


Figure 7. Average lipid normalized concentrations of pesticides and BDEs in juvenile (n $=2$ ) and adult $(\mathrm{n}=3)$ krill samples. $\alpha-\mathrm{HCH}$ was not quantifiable in juvenile krill samples, and heptachlor was not quantifiable in adult krill samples. $\gamma-\mathrm{HCH}$ in adult krill was detected in 2 samples; 1 sample $=$ NQ (not quantifiable) and a value of zero was used for calculation. ${ }^{*}=\mathrm{p}<0.05$ for difference between juvenile and adult krill (t-test on log transformed data). Error bars represent standard error. 


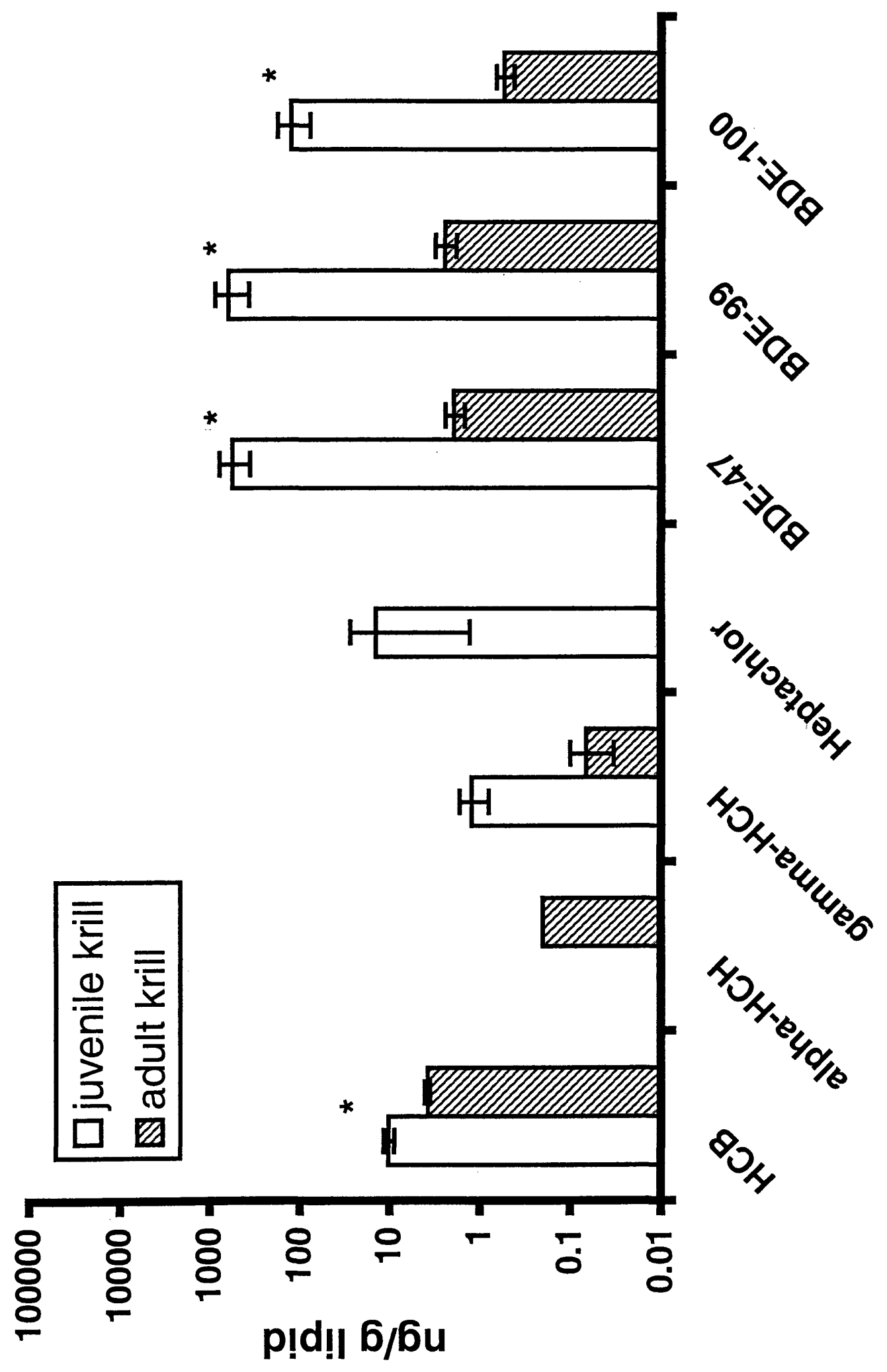


Eggs of zooplankton are lipid-rich, and PCB concentrations in Acartia tonsa eggs have been found to be $\sim 4$ times higher than the original concentration in the body of the female (McManus et al., 1983). Juvenile stages of zooplankton generally have high organochlorine levels after yolk absorption, and higher levels of hydrocarbons have been found in juvenile Euphausia superba compared to adult males, on a wet weight basis (Cripps, 1990). Thus, some portion of contaminant in juvenile krill may have been acquired during the egg stage, rather than by accumulation via consumption or absorption.

The average $\mathrm{HCB}$ concentration ( $0.11 \mathrm{ng} / \mathrm{g}$ wet weight) in my adult krill samples is comparable with the HCB concentration ( $0.2 \mathrm{ng} / \mathrm{g}$ wet weight) found by Corsolini et al. (2002) in Euphausia superba from the Ross Sea, Antarctica. However, the average concentration of $\Sigma \mathrm{HCH}(0.009 \mathrm{ng} / \mathrm{g}$ wet weight $)$ in my adult krill samples was much lower than that $(0.71 \mathrm{ng} / \mathrm{g}$ wet weight, converted using 0.216 wet:dry ratio (Hofmann and Lascara, 2000)) found by Gupta et al. (1996). This difference may be due to differences in the sampling region or time. $\mathrm{HCH}$ concentrations in air close to the sampling site of Gupta et al. (1996) on the east side of the continent (Larsson et al., 1992) were 10 times higher than observed for simultaneously collected air samples during this study (Cincinelli and Dickhut, 2003). The decline in Antarctic $\mathrm{HCH}$ concentrations with time is also reflected in plankton data (Figure 4).

While a number of studies have shown biomagnification between plankton and fish (Harding et al., 1997; Evans et al., 1991), increases in contaminant concentrations within lower planktonic trophic levels are less often seen. For example, Hargrave et al. (2000) 
found no biomagnification of organochlorines ( $\alpha$ - and $\gamma$ - HCH, HCB, DDTs) between plankton size classes in the Arctic. However, few studies have investigated biomagnification between krill and their food, or between krill life stages. Fowler and Elder (1978 in Harding, 1986) found no trophic magnification in a microzooplanktoneuphausiid-shrimp food chain in the Mediterranean. However, these authors did not compare values on a lipid weight basis. Harding et al. (1997) found an increase in PCB concentration with age for organisms with a life span greater than 1 year (fish), and longer life-spans have been suggested to lead to increased biomagnification in fish (Kidd et al., 1998) and other marine organisms (Hargrave et al., 1992). Given the long life span of krill (6-7 years) compared to other zooplankton (Quetin et al., 1996), I expected to see biomagnification, particularly in adult krill. My findings of no biomagnification between ice algae and juvenile krill, or between plankton and adult krill, were therefore surprising.

The absence of biomagnification for $\mathrm{HCB}$ is more likely than for the BDEs, given the physical-chemical characteristics of this compound. Bioaccumulation and biomagnification through the food web are partly dependent on the physical-chemical characteristics of pollutants, primarily the octanol-water partition coefficient $\left(\mathrm{K}_{\mathrm{ow}}\right)$ (Stange and Swackhamer, 1994). Although POPs in general are hydrophobic and lipophilic, within this class of compounds, characteristics that affect bioaccumulation through the food web vary. Russell et al. (1999) found that chemicals with $\log K_{\text {ow }}>6.3$ biomagnified in a food web containing zooplankton, benthic invertebrates and fish, while chemicals with $\log \mathrm{K}_{\mathrm{ow}} \leq 5.5$ (including $\mathrm{HCB}, \log \mathrm{K}_{\mathrm{ow}}=5.5$ ) did not. Hargrave et al. (1992) also found that $\mathrm{HCHs}\left(\log \mathrm{K}_{\mathrm{ow}}=3.8\right)$ and $\mathrm{HCB}$, despite being the most abundant 
organochlorines in air and seawater samples from the Canadian Arctic, were present in low concentrations in biota. In a food web study from the Baltic Sea, HCHs were found to have biomagnification factors around 1, indicating no biomagnification between trophic levels, and values for HCB were low compared to the other organochlorines studied (Strandberg et al., 1998). Similar to my results, Hargrave et al. (2000) also found meso- and macrozooplankton to contain similar amounts of $\alpha-\mathrm{HCH}$ as ice algae and phytoplankton, on a per lipid basis, and found $\mathrm{HCH}$ to be the least bioaccumulated of the organochlorines studied.

Lack of biomagnification for HCB may reflect the uptake mechanisms of the contaminants. Zooplankton, including crustaceans, can become contaminated through ingestion of contaminated food, or by passive accumulation from water in internal lipid pools (Joiris et al., 1997). The mode of uptake varies depending on the characteristics of each contaminant, with lower $\mathrm{K}_{\mathrm{ow}}$, more water soluble compounds bioavailable via passive uptake from water. If krill accumulate contaminants solely by equilibrium absorption into their lipids from water, we would expect to see similar concentrations in plankton and adult krill on a per lipid basis. HCB was present in similar concentrations per lipid in plankton and adult krill, suggesting passive uptake by equilibrium partitioning as the primary mechanism of uptake of this contaminant by krill.

Despite no difference in BDE concentrations between ice algae and juvenile krill (Figure 5), equilibrium partitioning of these contaminants between water and juvenile krill is unlikely because of their high $\mathrm{K}_{\mathrm{ow}}$ values. The lower solubility and higher $\mathrm{K}_{\mathrm{ow}}\left(\log \mathrm{K}_{\mathrm{ow}}\right.$ 
$>6.5$ ) of BDEs does not suggest a high dissolved under-ice or water column concentration for these compounds. Instead, BDEs would likely be more bioavailable absorbed to ice algae or plankton, and would be taken up by juvenile and adult krill via ingestion. Biomagnification would therefore be more likely for BDEs. Also, since biomagnification increases with age, it would be more likely in adult krill. Still, a number of factors can be hypothesized to account for the lack of biomagnification for BDEs between ice algae and juvenile krill, and especially for the significant decrease in $\mathrm{BDE}$ concentrations between plankton and adult krill.

First, it is important to note that my sampling method may have led to higher contaminant concentrations in ice algae than were actually present in the ice column. Because melted ice samples were passed through a GFF filter for particulate matter collection, dissolved phase compounds in ice may have absorbed to particles during filtration, causing an overrepresentation of the fraction associated with ice algae. However, this potential overcollection would only occur if contaminant partitioning between ice and ice algae were not already at equilibrium. Swackhamer and Skoglund (1993) showed that under low temperature, slow growth conditions, algae reached equilibrium with $\mathrm{PCBs}$ in water after about 20 days. Given the environmental conditions associated with sea ice it is likely that the ice algae were under slow growth conditions, and had presumably reached equilibrium with contaminants in sea ice prior to our sampling at the end of winter. Thus, it is unlikely that the measured ice algae concentrations were influenced by the collection method. Moreover, this potential sampling artifact would not have been a factor 
controlling the significantly lower BDE concentrations in adult krill compared to phytoplankton (Figure 6).

Increasing lipid content in adult krill during summer could lead to biodilution of contaminants during trophic transfer. In the Arctic, zooplankton synthesize lipids during summer as energy reserves (Kattner and Graeve, 1990 in Joiris et al., 1997). Seasonal accumulation of lipids during summer by Antarctic krill has also been observed (Hagen et al., 1996). An increase in lipid reserves in Arctic zooplankton has been hypothesized to lead to a dilution of PCBs, and was suggested to explain lower PCB concentrations in Arctic zooplankton than particulate matter on a lipid weight basis (Joiris et al., 1997). Delbeke et al. (1990) also attributed a lower PCB concentration in zooplankton compared to particulate matter on a lipid weight basis to a dilution of contaminants in autogenically formed lipids. Since these lipids are contaminant free, an increase in lipid reserves at a faster rate than contaminant uptake by krill feeding on plankton may have played a role in diluting contaminants, particularly the BDEs, during this initial trophic transfer. Accumulation of lipid reserves in adult krill during summer may also explain the observed dilution of BDEs in adult compared to juvenile krill collected in winter (Figure 7).

Growth dilution is a similar explanation for the decreases in POP concentrations between juvenile and adult krill. Growth dilution of POPs has been described for phytoplankton, and occurs when the individual growth rate of phytoplankton cells is faster than the uptake rate of POPs, resulting in a dilution of the pollutant in the growing biomass of the 
cell, and a decreased concentration per unit of lipid biomass (Andersson et al., 1998; Larsson et al., 2000). Growth dilution has been suggested as an explanation for the inverse relationship between krill (Euphausia superba) length and mercury concentration (Palmer Locarnini and Presley, 1995). This mechanism is similar to the dilution by production of lipid reserves described above, which offered an explanation for the decrease in BDEs between plankton and adult krill.

Biomagnification factors less than one also occur when the rate of elimination exceeds that of uptake of a compound. Such elimination could have played a role in decreasing levels of BDEs in adult krill compared to plankton, or in leading to similar BDE concentrations between ice algae and juvenile krill rather than biomagnification. Organisms at higher trophic levels (i.e., mammals) generally have a higher capacity to metabolize persistent organochlorines (Strandberg et al., 1998). This capability is also suggested for longer-lived plankton (Hargrave et al., 1992), such as copepods (Harding, 1986), and may be likely for krill given their relatively long life span. It can be hypothesized that this process would be more important for elimination of BDEs compared to $\mathrm{HCB}$, since $\mathrm{BDEs}$ have vicinal $\mathrm{C}-\mathrm{H}$ pairs that would allow for biodegradation via the monooxygenase pathway (Porte and Albaiges, 1993), whereas HCB does not. However, if metabolism of BDEs by krill were significant, a greater difference would be expected between plankton and krill for BDE-47 compared to BDE99 and -100 concentrations, as the former has twice as many vicinal $\mathrm{C}-\mathrm{H}$ pairs, and thus a greater potential for elimination via metabolism. This was not observed. Also, BDE-47 and -99 have been shown to be poorly metabolized by rats (Hardy, 2002). 
Egestion is another mechanisms by which zooplankton can eliminate contaminants. PCB concentrations in krill fecal pellets were higher than in euphausiid bodies or molts (Elder and Fowler, 1977). Feces have accounted for 14 and $43 \%$ of elimination of BDE 47 and 99, respectively, in rats (Hardy, 2002). These results, and the similarity of BDE structure to PCBs, suggest that egestion may account for some of the decrease I observed for BDEs in adult krill compared to their food source, and for the lack of biomagnification between ice algae and juvenile krill.

Finally, it may also be hypothesized that BDEs are too large to be efficiently taken up by krill, thus leading to significantly lower levels in adult krill compared to plankton. The molecular configuration of a chemical is known to affect the bioaccumulation of organic contaminants (e.g. Stange and Swackhamer, 1994). However, I analyzed for tetra- and penta- BDEs, which have a relatively high potential for bioaccumulation as previously demonstrated (Hardy, 2002).

\section{CONCLUSIONS}

Despite limited sample sizes, my results provide valuable information on levels of POPs in lower Antarctic trophic levels, including BDEs, for which no results from Antarctica, or on phytoplankton or zooplankton anywhere, have been published. My results provide insight into uptake of contaminants by juvenile krill feeding on ice algae, which has not been previously investigated. These results suggest that sea ice does contribute contaminants to higher trophic levels in polar food webs, a question which was posed for 
the Arctic by Pfirman et al. (1995). In the Antarctic, the contribution of contaminants to higher trophic levels by sea ice occurs directly via feeding by juvenile krill on ice algae, but may also include contaminant uptake by plankton and adult krill following ice melt. By both of these mechanisms, therefore, sea ice does appear to provide a controlling vector for entry of POPs into the Antarctic environment and food web.

The absence of POP biomagnification between plankton and krill samples was surprising, given the long life span of these organisms. The significant decrease for BDEs between plankton and adult krill was particularly surprising, given the high potential $\left(\log \mathrm{K}_{\mathrm{ow}}>\right.$ 6.5) for biomagnification of these compounds. It is also interesting that while the average $\mathrm{BDE}$ concentration was significantly higher than $\mathrm{HCB}$ concentration in ice algae and plankton ( $p<0.05$; d.f. $=3$ and 23 , respectively), this contrast was not the case in juvenile or adult krill. BDEs may not be transferred to higher trophic levels in any higher concentrations than pesticides such as $\mathrm{HCB}$, despite the significantly higher input of BDEs to the Antarctic coastal ecosystem, and their higher concentration than pesticides in the lowest trophic levels. 


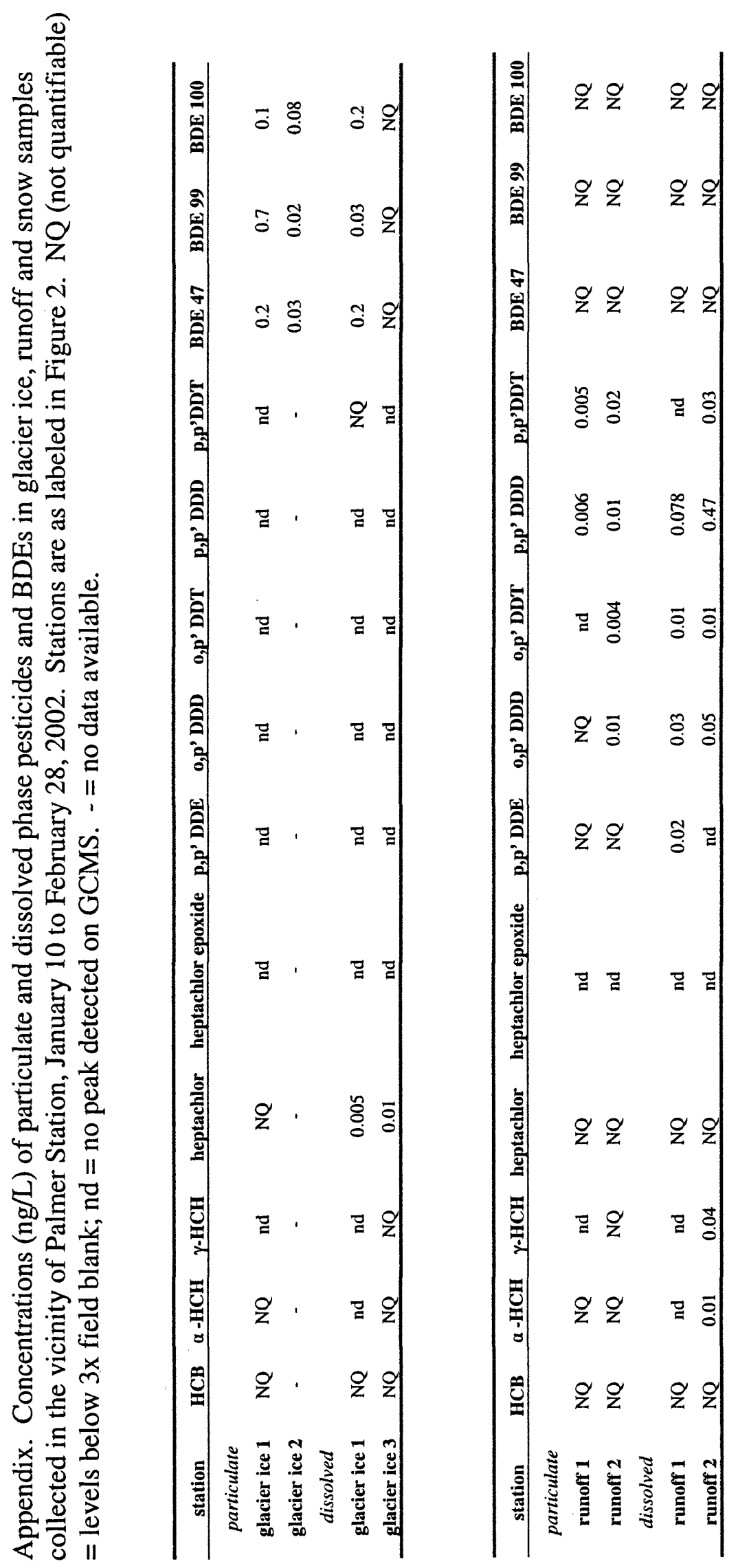




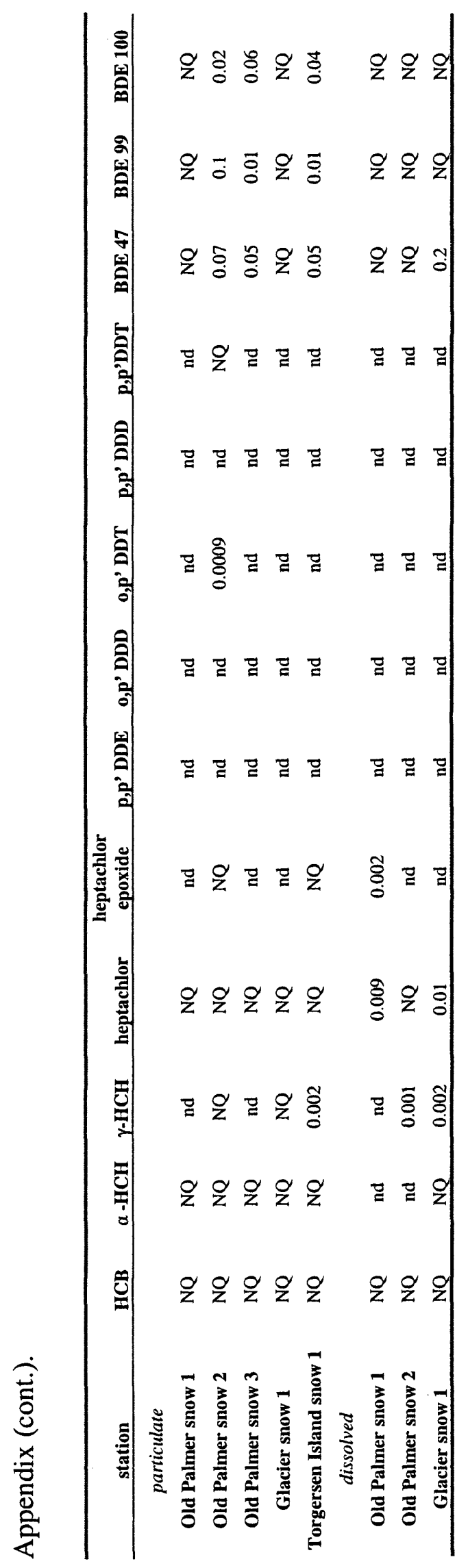




\section{LITERATURE CITED}

Ackley, S.F. and C.W. Sullivan. 1994. Physical controls on the development and characteristics of Antarctic sea ice biological communities - a review and synthesis. Deep Sea Research. 41(10):1583-1604.

Alaee, M., J. Luross, D.B. Sergeant, D.C.G. Muir, D.M. Whittle, and K. Solomon. 1999. Distribution of polybrominated diphenyl ethers in the Canadian environment. Organohalogen Compounds. 40:347-350.

Alaee, M. and R.J. Wenning. 2002. The significance of brominated flame retardants in the environment: current understanding, issues and challenges. Chemosphere. 46:579-582.

Anadón, R., F. Alvarez-Marqués, E. Fernández, M. Varela, M. Zapata, J.M. Gasol and D. Vaqué. 2002. Vertical biogenic particle flux during Austral summer in the Antarctic Peninsula area. Deep-Sea Research II. 49:883-901.

Andersson, A., P. Wallberg, J. Nordbäck, P.A. Bergqvist and E. Selstam. 1998. Effect of nutrient enrichment on the distribution and sedimentation of polychlorinated biphenyls (PCBs) in seawater. Hydrobiologia. 377:45-56.

Aono, S., S. Tanabe, Y. Fujise, H. Kato and R. Tatsukawa. 1997. Persistent organochlorines in Minke whale (Balaenoptera acutorostrata) and their prey species from the Antarctic and the North Pacific. Environmental Pollution. 98:81-89.

Baker, J.E., S.J. Eisenreich and B.J. Eadie. 1991. Sediment trap fluxes and benthic recycling of organic carbon, polycyclic aromatic hydrocarbons, and polychlorobiphenyl congeners in Lake Superior. Environmental Science and Technology. 25:500-509.

Bard, S.M. 1999. Global transport of anthropogenic contaminants and the consequences for the Arctic marine ecosystem. Marine Pollution Bulletin. 38(5):356-379.

Barrie, L.A., D. Gregor, B. Hargrave, R. Lake, D. Muir, R. Shearer, B. Tracey and T. Bidleman. 1992. Arctic contaminants: Sources, occurrence and pathways. The Science of the Total Environment. 122:1-74.

Bidigare, R.R., J.L. Iriarte, S.H. Kang, D. Karentz, M.E. Ondrusek and G.A. Fryxell. 1996. Phytoplankton: Quantitative and qualitative assessments, in Foundations for Ecological Research West of the Antarctic Peninsula, edited by Ross, R.M., E.E. Hofmann and L.B. Quetin, (AGU Antarctic Research Series, vol. 70). Pp. 173-198. 
Bidleman, T.F., M.D. Walla, R. Roura, E. Carr and S. Schmidt. 1993. Organochlorine pesticides in the atmosphere of the Southern Ocean and Antarctica, JanuaryMarch, 1990. Marine Pollution Bulletin. 26(5):258-262.

Blais, J.M., D.W. Schindler, D.C.G. Muir, M. Sharp, D. Donald, M. Lafreniére, E. Braekevelt and W.M.J. Strachan. 2001. Melting glaciers: A major source of persistent organochlorines to subalpine Bow Lake in Banff National Park, Canada. Ambio. 30(7):410-415.

Bode, A., C. G. Castro, M. D. Doval and M. Varela. 2002. New and regenerated production and ammonium regeneration in the western Bransfield Strait region (Antarctica) during phytoplankton bloom conditions in summer. Deep Sea Research II. 49:787-804.

Burkow, I.C. and R. Kallenborn. 2000. Sources and transport of persistent pollutants to the Arctic. Toxicology Letters. 112-113:87-92.

Burns, K.A., J.P. Villeneuve and S.W. Fowler. 1985. Fluxes and residence times of hydrocarbons in the coastal Mediterranean: How important are the biota? Estuarine, Coastal and Shelf Science. 20:313-330.

Calamari, D., E. Bacci, S. Focardi, C. Gaggi, M. Morosini and M. Vighi. 1991. Role of plant biomass in the global environmental partitioning of chlorinated hydrocarbons. Environmental Science and Technology. 25:1489-1495.

Chernyak, S.M., C.P. Rice and L.L. McConnell. 1996. Evidence of currently-úsed pesticides in air, ice, fog, seawater and surface microlayer in the Bering and Chukchi Seas. Marine Pollution Bulletin. 32(5):410-419.

Cincinelli, A. and R.M. Dickhut. 2003. Persistent Organic Pollutants in Antarctic air. Poster at the Annual meeting of the Society of Environmental Toxicology and Chemistry (SETAC) Europe. Hamburg, Germany, April 2003.

Corsolini, S., K. Kannan, T. Imagawa, S. Focardi and J.P. Giesy. 2002. Polychloronapthalenes and other dioxin-like compounds in Arctic and Antarctic marine food webs. Environmental Science and Technology. 36:3490-3496.

Cripps, G.C. 1990. Hydrocarbons in the seawater and pelagic organisms of the Southern Ocean. Polar Biology. 10:393-402.

Dachs, J., S.J. Eisenreich and R.M. Hoff. 2000. Influence of eutrophication on air-water exchange, vertical fluxes, and phytoplankton concentrations of persistent organic pollutants. Environmental Science and Technology. 34:1095-1102. 
Daly, K.L. 1998. Physioecology of juvenile Antarctic krill (Euphausia superba) during spring in ice-covered seas, in Antarctic Sea Ice Biological Processes, Interactions, and Variability, edited by Lizotte, M.P., and K.R. Arrigo, (Antarctic Research Series, vol. 73). Pp. 183-198.

de Boer, J. and W.P Cofino. 2002. First world-wide interlaboratory study on polybrominated diphenylethers (PBDEs). Chemosphere. 46:625-633.

de Wit, C.A. 2002. An overview of brominated flame retardants in the environment. Chemosphere. 46:583-624.

del Vento, S. and J. Dachs. 2002. Prediction of uptake dynamics of persistent organic pollutants by bacteria and phytoplankton. Environmental Toxicology and Chemistry. 21(10):2099-2107.

Delbeke, K., C.R. Joiris, and M. Bossicart. 1990. Organochlorines in different fractions of sediments and in different planktonic compartments of the Belgian Continental Shelf and the Scheldt Estuary. Environmental Pollution. 66:325-349.

Desideri, P., L. Lepri, D. Santianni and L. Checchini. 1991. Chlorinated pesticides in sea water and pack ice in Terra Nova Bay (Antarctica). Annali di Chimica. 81:533 -540 .

Dickhut, R.M. and K.E. Gustafson. 1995. Atmospheric Inputs of Selected Polycyclic Aromatic Hydrocarbons and Polychlorinated Biphenyls to Southern Chesapeake Bay. Marine Pollution Bulletin. 30(6):385-396.

Donald, D.B., J. Syrgiannis, R.W. Crosley, G. Holdsworth, D.C.G. Muir, B. Rosenberg, A. Sole and D.W. Schindler. 1999. Delayed deposition of organochlorine pesticides at a temperate glacier. Environmental Science and Technology. 33:1794-1798.

Elder, D.L. and S.W. Fowler. 1977. Polychlorinated biphenyls: Penetration into the deep ocean by zooplankton fecal pellet transport. Science. 197:459-461.

Evans, M.S., G.E. Noguchi and C.P. Rice. 1991. The biomagnification of polychlorinated biphenyls, toxaphene, and DDT compounds in a Lake Michigan offshore food web. Archives of Environmental Contamination and Toxicology. 20:87-93.

Falconer, R.L., T.F. Bidleman and D.J. Gregor. 1995. Air-water gas exchange and evidence for metabolism of hexachlorocyclohexanes in Resolute Bay, N.W.T. The Science of the Total Environment. 160/161: 65-74.

Friedmann, E.I. and A.B. Thistle. 1993. Foreword, in Antarctic Microbiology, edited by E.I. Friedmann. Pp. ix-x. 
Fuoco, R., M.P. Colombini and C. Abete. 1994. Determination of polychlorobiphenyls in environmental samples. from Antarctica. International Journal of Environmental Analytical Chemistry. 55:15-25.

Garrison, A.W., V.A. Nzengung, J.K. Avants, J. J. Ellington, W.J. Jones, D. Rennels and N.L. Wolfe. 2000. Phytodegradation of p,p'-DDT and the enantiomers of o,p' -DDT. Environmental Science and Technology. 34:1663-1670.

Garrison, D.L. 1991. Antarctic sea ice biota. American Zoology. 31:17-33.

Garrison, D.L., C.W. Sullivan and S.F. Ackley. 1986. Sea ice microbial communities in Antarctica. Bioscience. 36(4):243-250.

Garrison, D.L. and S. Mathot. 1996. Pelagic and sea ice microbial communities, in Foundations for Ecological Research West of the Antarctic Peninsula, edited by Ross, R.M., E.E. Hofmann and L.B. Quetin, (AGU Antarctic Research Series, vol. 70). Pp. 155-172.

Gaul, H. 1989. Organochlorine compounds in water and sea ice of the European Arctic Sea. In: $8^{\text {th }}$ International Conference of Comite Arctique International, Oslo, Sept. 18-22, 1989.

Green, G., J.H. Skerratt, R. Leeming and P.D. Nichols. 1992. Hydrocarbon and Coprostanol levels in seawater, sea-ice algae and sediments near Davis Station in Eastern Antarctica: A regional survey and preliminary results for a field fuel oil spill experiment. Marine Pollution Bulletin. 25(9-12):293-302.

Gregor, D.J. 1991. Trace organic chemicals in the Arctic environment: atmospheric transport and deposition, in Pollution of the Arctic Atmosphere, edited by W.T. Sturges. Pp. 217-254.

Gregor, D.J. and W.D. Gummer. 1989. Evidence of atmospheric transport and deposition of organochlorine pesticides and polychlorinated biphenyls in Canadian Arctic snow. Environmental Science and Technology. 23(5):561-565.

Gregor, D.J., A.J. Peters, C. Teixeira, N. Jones and C. Spencer. 1995. The historical residue trend of PCBs in the Agassiz Ice Cap, Ellesmere Island, Canada. The Science of the Total Environment. 160/161:117-126.

Gupta, R.S., A. Sarkar and T.W. Kureishey. 1996. PCBs and organochlorine pesticides in krill, birds and water from Antarctica. Deep-Sea Research II. 43(1):119-126.

Gustafson K.E. and R.M. Dickhut. 1997. Gaseous exchange of polycyclic aromatic hydrocarbons across the air-water interface of southern Chesapeake Bay. Environmental Science and Technology. 31:1623-1629. 
Hagen, W., V. E.S. Van Vleet and K. Gerhard. 1996. Seasonal lipid storage as overwintering strategy of Antarctic krill. Marine Ecology Progress Series. 134(1 $-3): 85-89$.

Harding, G.C. 1986. Organochlorine dynamics between zooplankton and their environment, a reassessment. Marine Ecology Progress Series. 33:167-191.

Harding, G.C., R.J. LeBlanc, W.P. Vass, R.F. Addison, B.T. Hargrave, S. Pearre Jr., A. Dupuis and P.F. Brodie. 1997. Bioaccumulation of polychlorinated biphenyls (PCBs) in the marine pelagic food web, based on a seasonal study in the southern Gulf of St. Lawrence, 1976-1977. Marine Chemistry. 56:145-179.

Hardy, M.L. 2002. The toxicology of the three commercial polybrominated diphenyl oxide (ether) flame retardants. Chemosphere. 46:757-777.

Hargrave, B.T., W.P. Vass, P.E. Erickson and B.R. Fowler. 1988. Atmospheric transport of organochlorines to the Arctic Ocean. Tellus. 40B:480-493.

Hargrave, B.T., G.C. Harding, W.P. Vass, P.E. Erickson, B.R. Fowler and V. Scott. 1992. Organochlorine pesticides and polychlorinated biphenyls in the Arctic Ocean food web. Archives of Environmental Contamination and Toxicology. 22:41-54.

Hargrave, B.T., L.A. Barrie, T.F. Bidleman and H.E. Welch. 1997. Seasonality in exchange of organochlorines between Arctic air and seawater. Environmental Science and Technology. 31:3258-3266.

Hargrave, B.T., G.A. Phillips, W.P. Vass, P. Bruecker, H.E. Welch and T.D. Siferd. 2000. Seasonality in bioaccumulation of organochlorines in lower trophic level Arctic marine biota. Environmental Science and Technology. 34:980-987.

Hoff, J.T., F. Wania, D. Mackay and R. Gillham. 1995. Sorption of nonpolar organic vapors by ice and snow. Environmental Science and Technology. 29:1982-1989.

Hofmann, E.E. and C.M. Lascara. 2000. Modeling the growth dynamics of Antarctic krill Euphausia superba. Marine Ecology Progress Series. 194:219-231.

Holm-Hansen, O. and M. Huntley. 1984. Feeding requirements of krill in relation to food sources. Journal of Crustacean Biology. 4(1):156-173.

Hornbuckle, K.C., J. D. Jeremiason, C.W. Sweet and S.J. Eisenreich. 1994. Seasonal variations in air-water exchange of polychlorinated biphenyls in Lake Superior. Environmental Science and Technology. 28:1491-1501. 
Ikonomou, M.G., M. Fischer, T. He, R.F. Addison and T. Smith. 2000. Congener patterns, spatial and temporal trends of polybrominated diphenyl ethers in biota samples from the Canadian west coast and the Northwest Territories. Organohalogen Compounds. 47:77-80.

Ikonomou, M.G., S. Rayne and R.F. Addison. 2002. Exponential increases of the brominated flame retardants, polybrominated diphenyl ethers, in the Canadian Arctic from 1981 to 2000. Environmental Science and Technology. 36:18861892.

Inomata, O.N.K., R.C. Montone, W.H. Lara, R.R. Weber and H.H.B. Toledo. 1996. Tissue distribution of organochlorine residues -PCBs and pesticides- in Antarctic penguins. Antarctic Science. (8):253-255.

Jansson, B., L. Asplund and M. Olsson. 1987. Brominated flame retardants - ubiquitous environmental pollutants? Chemosphere. 16:2343-2349.

Jeremiason, J.D., S.J. Eisenreich, and M.J. Paterson. 1999. Accumulation and recycling of PCBs and PAHs in artificially eutrophied Lake 227. Canadian Journal of Fisheries and Aquatic Sciences. 56(4):650-660.

Joiris, C.R. and W. Overloop. 1991. PCBs and organochlorine pesticides in phytoplankton and zooplankton in the Indian sector of the Southern Ocean. Antarctic Science. 3(4):371-377.

Joiris, C.R., N. Laroussi Moatemri and L. Holsbeek. 1997. Mercury and polychlorinated biphenyls in zooplankton and shrimp from the Barents Sea and the Spitsbergen area. Bulletin of Environmental Contamination and Toxicology. 59:472-478.

Kallenborn, R., M. Oehme, D.D. Wynn-Williams, M. Schlabach and J. Harris. 1998. Ambient air levels and atmospheric long-range transport of persistent organochlorines to Signey Island, Antarctica. The Science of the Total Environment. 220:167-180.

Kannan, K., S. Tanabe and R. Tatsukawa. 1995. Geographical distribution and accumulation features of organochlorine residues in fish in tropical Asia and Oceania. Environmental Science and Technology. 29(10):2673-2683.

Karl, D.M., B.D. Tilbrook and G. Tien. 1991. Seasonal coupling of organic matter production and particle flux in the western Bransfield Strait, Antarctica. Deep-Sea Research. 38(8/9):1097-1126. 
Karl, D.M., J.R. Christian and J.E. Dore. 1996. Microbiological oceanography in the region west of the Antarctic Peninsula: Microbial dynamics, nitrogen cycle and carbon flux, in Foundations for Ecological Research West of the Antarctic Peninsula, edited by Ross, R.M., E.E. Hofmann, and L.B. Quetin, (AGU Antarctic Research Series, vol. 70). Pp. 303-332.

Kennicutt, M.C. II and S.J. McDonald. 1996. Marine disturbance - Contaminants, in Foundations for Ecological Research West of the Antarctic Peninsula, edited by Ross, R.M., E.E. Hofmann, and L.B. Quetin, (AGU Antarctic Research Series, vol. 70). Pp. 401-415.

Kidd, K.A., R.H. Hesslein, B.J. Ross, K. Koczanski, G.R. Stephens and D.C.G. Muir. 1998. Bioaccumulation of organochlorines through a remote freshwater food web in the Canadian Arctic. Environmental Pollution. 102:91-103.

Kottmeier, S.T. and C.W. Sullivan. 1987. Late winter primary production and bacterial production in sea ice and seawater west of the Antarctic Peninsula. Marine Ecology Progress Series. 36:287-298.

Larsson, P., C. Järnmark and A. Södergren. 1992. PCBs and chlorinated pesticides in the atmosphere and aquatic organisms of Ross Island, Antarctica. Marine Pollution Bulletin. 25(9-12):281-287.

Larsson, P., A. Andersson, D. Broman, J. Nordbäck and E. Lundberg. 2000. Persistent organic pollutants (POPs) in pelagic systems. Ambio. 29(4-5):202-209.

Li, Y.F., T.F. Bidleman, L.A. Barrie and L.L. McConnell. 1998. Global hexachlorocyclohexane use trends and their impact on the arctic atmospheric environment. Geophysical Research Letters. 25(1):39-41.

Luckas, B., W. Vetter, P. Fischer, G. Heidemann and J. Plötz. 1990. Characteristic chlorinated hydrocarbon patterns in the blubber of seals from different marine regions. Chemosphere. 21(1-2):13-19.

Lukowski, A.B. 1978. DDT and its metabolites in Antarctic Krill (Euphausia superba dana) from South Atlantic. Polish Archives Hydrobiology. 25(3):663-668.

Lukowski, A.B. and R. Ligowski. 1987. Cumulation of chloroorganic insecticides by Antarctic marine diatoms. Polish Polar Research. 8(2):167-177.

Lukowski, A.B. and R. Ligowski. 1988. Contamination of Antarctic marine phytoplankton by chlorinated hydrocarbons (BIOMASS III). Polish Polar Research. 9(2-3):399-408. 
McManus, G.B., Wyman, K.D., Peterson, W.T. and C.F. Wurster. 1983. Factors affecting the elimination of PCBs in the marine copepod Acartia tonsa. Estuarine Coastal and Shelf Science. 17:421-430.

Norstrom, R.J., S.E. Belikov, E.W. Born, G.W. Garner, B. Malone, S. Olpinski, M.A. Ramsay, S. Schliebe, I. Stirling, M.S. Stishov, M.K. Taylor and Ø. Wiig. 1998. Chlorinated hydrocarbon contaminants in polar bears from Eastern Russia, North America, Greenland, and Svalbard: Biomonitoring of Arctic pollution. Archives of Environmental Contamination and Toxicology. 35:354-367.

Oehme, M., M. Schlabach, R. Kallenborn and J.E. Haugen. 1996. Sources and pathways of persistent polychlorinated pollutants to remote areas of the North Atlantic and levels in the marine food chain: A research update. The Science of the Total Environment. 186:13-24.

Olsson, M. and S. Jensen. 1975. Pike as the test organism for mercury, DDT and PCB pollution. A study of the contamination in the Stockholm archipelago. Institute of Freshwater Research Report, Drottningholm. 54:83-106.

Palmer Locarnini, S.J. and B.J. Presley. 1995. Trace element concentrations in Antarctic krill, Euphausia superba. Polar Biology. 15:283-288.

Palmisano A.C. and D.L. Garrison. 1993. Microorganisms in Antarctic sea ice, in Antarctic Microbiology, edited by E.I. Friedmann. Pp. 167-218.

Peel, D.A. 1975. Organochlorine residues in Antarctic snow. Nature. 254:324-325.

Peterle, T.J. 1969. DDT in Antarctic snow. Nature. 224:620.

Pfirman, S.L., H. Eicken, D. Bauch and W.F. Weeks. 1995. The potential transport of pollutants by Arctic sea ice. The Science of the Total Environment. 159:129-146.

Porte, C. and J. Albaiges. 1993. Bioaccumulation patterns of hydrocarbons and polychlorinated biphenyls in bivalves, crustaceans, and fishes. Archives of Environmental Contamination and Toxicology. 26:273-281.

Prezelin, B.B., E.E. Hofmann, C. Mengelt and J.M. Klinck. 2000. The linkage between Upper Circumpolar Deep Water (UCDW) and phytoplankton assemblages on the west Antarctic Peninsula continental shelf. Journal of Marine Research. 58(2):165-202.

Quetin, L.B., R.M. Ross, T.K. Frazer and K.L. Haberman. 1996. Factors affecting distribution and abundance of zooplankton, with an emphasis on Antarctic Krill, Euphausia superba, in Foundations for Ecological Research West of the Antarctic Peninsula, edited by Ross, R.M., E.E. Hofmann and L.B. Quetin, (AGU Antarctic Research Series, vol. 70). Pp. 357-371. 
Risebrough, R.W., W. Walker II, T.T. Schmidt, B.W. de Lappe and C.W. Connors. 1976. Transfer of chlorinated biphenyls to Antarctica. Nature. 264:738-739.

Ross, R.M. and L.B. Quetin. 1986. How productive are Antarctic krill? Bioscience. 36(4):264-268.

Ross, R.M., L.B. Quetin and C.M. Lascara. 1996. Distribution of Antarctic krill and dominant zooplankton west of the Antarctic Peninsula, in Foundations for Ecological Research West of the Antarctic Peninsula, edited by Ross, R.M., E.E. Hofmann and L.B. Quetin, (AGU Antarctic Research Series, vol. 70). Pp. 199217.

Russell, R.W., F.A.P.C. Gobas and G.D. Haffner. 1999. Role of chemical and ecological factors in trophic transfer of organic chemicals in aquatic food webs. Environmental Toxicology and Chemistry. 18(6):1250-1257.

Schafer, K.S. 2002. From the dirty dozen to POPs - Winning the battle to eliminate persistent pollutants. Global Pesticide Caimpaigner. 12(1): 12-16.

Serret, P., E. Fernández, R. Anadón and M. Varela. 2001. Trophic control of biogenic carbon export in Bransfield and Gerlache Straits, Antarctica. Journal of Plankton Research. 23(12):1345-1360.

Sladen W.J.L., C.M. Menzie and W.L. Reichel. 1966. DDT residues in adelie penguins and a Crabeater seal from Antarctica. Nature. 210:670-673.

Smith, R.C., K.S. Baker, W.R. Fraser, E.E. Hofmann, D.M. Karl, J.M. Klinck, L.B. Quetin, B.B. Prézelin, R.M. Ross, W.Z. Trivelpiece and M. Vernet. 1995. The Palmer LTER: A long-term ecological research program at Palmer Station, Antarctica. Oceanography. 8(3):77-86.

Smith, R.C., H.M. Dierssen and M. Vernet. 1996. Phytoplankton biomass and productivity in the western Antarctic Peninsula region, in Foundations for Ecological Research West of the Antarctic Peninsula, edited by Ross, R.M., E.E. Hofmann and L.B. Quetin, (AGU Antarctic Research Series, vol. 70). Pp. 333356.

Smith, R.C., K.S., Baker, M.L. Byers and S.E. Stammerjohn. 1998a. Primary Productivity of the Palmer Long Term Ecological Research Area and the Southern Ocean. Journal of Marine Systems. 17(4):245-259.

Smith, R.C., K.S. Baker and M. Vernet. 1998b. Seasonal and interannual variability of phytoplankton biomass west of the Antarctic Peninsula. Journal of Marine Systems. 17:229-243. 
Smith, W.O. Jr. and D.M. Nelson. 1986. Importance of ice edge phytoplankton production in the Southern Ocean. Bioscience. 36(4):251-257.

Stange, K. and D.L. Swackhamer. 1994. Factors affecting phytoplankton species-specific differences in accumulation of 40 polychlorinated biphenyls (PCBs). Environmental Toxicology and Chemistry. 13(11):1849-1860.

Strandberg, B., C. Bandh, B. van Bavel, P.A. Bergqvist, D. Broman, C. Näf, H. Pettersen and C. Rappe. 1998. Concentrations, biomagnification and spatial variation of organochlorine compounds in a pelagic food web in the northern part of the Baltic Sea. The Science of the Total Environment. 217:143-154.

Stretch, J.J., P.P Hamner, W.M. Hamner, W.C. Michel, J. Cook and C.W. Sullivan. 1988. Foraging behavior of Antarctic krill Euphasia superba on sea ice microalgae. Marine Ecology Progress Series. 44:131-139.

Swackhamer, D.L. and R.S. Skoglund. 1991. The role of phytoplankton in the partitioning of hydrophobic organic contaminants in water, in Organic Substances and Sediments in Water. Vol 2. Processes and Analytical, edited by Baker, R.A. Pp. 91-105.

Swackhamer, D.L. and R.S. Skoglund. 1993. Bioaccumulation of PCBs by algae: Kinetics versus equilibrium. Environmental Toxicology and Chemistry. 12:831838.

Tanabe, S., H. Hidaka and R. Tatsukawa. 1983. PCBs and chlorinated hydrocarbon pesticides in Antarctic atmosphere and hydrosphere. Chemosphere. 12(2):277288.

Tatton, J.O'G. and J.H.A. Ruzicka. 1967. Organochlorine pesticides in Antarctica. Nature. 215:346-348.

Taylor, W.D., J.H. Carey, D.R.S. Lean and D.J. McQueen. 1991. Organochlorine concentrations in the plankton of lakes in southern Ontario and their relationship to plankton biomass. Canadian Journal of Fisheries and Aquatic Sciences. 48:1960- 1966.

Van den Brink, N.W. 1997. Directed transport of volatile organochlorine pollutants to polar regions: The effect on the contamination pattern of Antarctic seabirds. The Science of the Total Environment. 198:43-50.

Voldner, E.C. and Y.F. Li. 1995. Global usage of selected persistent organochlorines. The Science of the Total Environment. 160/161:201-210.

Wania, F. 1997. Modelling the fate of non-polar organic chemicals in an ageing snow pack. Chemosphere. 35(10):2345-2363. 
Wania, F. and D. Mackay. 1996. Tracking the distribution of persistent organic pollutants. Environmental Science and Technology. 30(9):390A-396A.

Wania, F., J.T. Hoff, C.Q. Jia and D. Mackay. 1998. The effects of snow and ice on the environmental behaviour of hydrophobic organic chemicals. Environmental Pollution. 102:25-41.

Wefer, G. 1989. Particle flux in the ocean: Effects of episodic production, in Productivity of the Ocean: Present and Past, edited by Berger, W.H., V.S. Smetacek and G. Wefer. Pp. 139-153

Wefer, G., G. Fischer, D. Füetterer and R. Gersonde. 1988. Seasonal particle flux in the Bransfield Strait, Antarctica. Deep-Sea Research. 35(6):891-898.

Weichbrodt, M., W. Vetter, E. Scholz, B. Luckas and K. Reinhardt. 1999. Determination of organochlorine levels in Antarctic skua and penguin eggs by application of combined focused open-vessel microwave-assisted extraction, gel-permeation chromatography, adsorption chromatography, and GC/EDC. International Journal of Environmental Analytical Chemistry. 73(4):309-328.

Welch, H.E., D.C.G. Muir, B.N. Billeck, W.L. Lockhart, G.J. Brunskill, H.J. Kling, M.P. Olson and R.M. Lemoine. 1991. Brown snow: A long-range transport event in the Canadian Arctic. Environmental Science and Technology. 25:280286.

Wolff, E. 1992. The influence of global and local atmospheric pollution on the chemistry of Antarctic snow and ice. Marine Pollution Bulletin. 25(9-12):274-280. 


\section{VITA}

Born in Danvers, MA, November 12, 1975. Attended Boston University in Boston, MA, and graduated with a B.A. in Environmental Science in 1998. Before attending graduate school, worked as a research intern in fisheries behavioral ecology at the Hatfield Marine Science Center in Newport, OR, and as an intern in wildlife ecology in Yellowstone National Park. Worked as a research technician in stream ecology at the H.J. Andrews Experimental Forest in Blue River, OR, and as a technician in salt marsh ecology at the Plum Island Ecosystem LTER site, for the Marine Biological Laboratory, Woods Hole, MA. Entered the M.S. program of the School of Marine Science, Virginia Institute of Marine Science, College of William and Mary in August 2000. Successfully defended M.S. thesis on August 4, 2003. Will take part in an Arctic research cruise during fall 2003. 